\title{
Citrus Viroids: Symptom Expression and Performance of Washington Navel Sweet Orange Trees Grafted on Carrizo Citrange
}

N. Murcia, S. M. Bani Hashemian, and P. Serra, Departamento de Protección Vegetal y Biotecnología, Instituto Valenciano de Investigaciones Agrarias, Apartado Oficial, 46113-Moncada, Valencia, Spain; J. A. Pina, Servicio de Semillas y Plantas de Vivero, Apartado Oficial, 46113-Moncada, Valencia, Spain; and N. Duran-Vila, Departamento de Protección Vegetal y Biotecnología, Instituto Valenciano de Investigaciones Agrarias, Apartado Oficial, 46113-Moncada, Valencia, Spain

\begin{abstract}
Murcia, N., Bani Hashemian, S. M., Serra, P., Pina, J. A., and Duran-Vila, N. 2015. Citrus viroids: Symptom expression and performance of Washington navel sweet orange trees grafted on Carrizo citrange. Plant Dis. 99:125-136.

Citrus are natural hosts of several viroid species. Citrus exocortis viroid (CEVd) and Hop stunt viroid (HSVd) are the causal agents of two well-known diseases of citrus, exocortis and cachexia. Other viroids have been found to induce specific symptoms and different degrees of stunting in trees grafted on trifoliate orange and trifoliate orange hybrids. A field assay was initiated in 1989 to establish the effect of CEVd, HSVd, Citrus bent leaf viroid (CBLVd), Citrus dwarfing viroid $(\mathrm{CDV})$, and Citrus bark cracking viroid $(\mathrm{CBCVd})$ on Washington navel sweet orange trees grafted on Carrizo citrange rootstock. Here we report the effect of viroid infection on symptom expression, tree size, fruit production and quality evaluated from 2004 to 2007 . Vegeta-

tive growth was affected by viroid infection with height and canopy volume being reduced. No bark scaling symptoms were observed in CEVd-infected trees albeit they presented lesions and blisters in the roots. Bark cracking symptoms were consistently observed in CBCVdinfected trees that were smaller with enhanced productivity and fruit size. No major effects were found as a result of infection with CBLVd, HSVd, or CDVd. The quality of the fruits was not affected by viroid infection, except for the low diameter of the fruits harvested from HSVd-infected trees. An interesting effect was identified in terms of tree productivity increase (yield/canopy volume) as a result of infection with CEVd, CDVd, and especially CBCVd.
\end{abstract}

Citrus exocortis disease was described in 1948 as a bark shelling or scaling disorder affecting trees grown on the trifoliate orange (Poncirus trifoliata (L.) Raf.) rootstock (13). Once graft transmission was demonstrated $(5,6)$, the disease was considered to be of viral etiology. With the discovery of viroids as a new class of plant pathogens (10), the exocortis disease was demonstrated to be associated with the Citrus exocortis viroid (CEVd) (44).

The use of Etrog citron (Citrus medica L.) for biological indexing purposes revealed a variety of symptoms which were erroneously considered, for many years, as evidence for the existence of CEVd strains (37). In 1985, Schlemmer et al. (39) provided the first evidence indicating that viroids other than CEVd were responsible for the mild and moderate symptoms observed on inoculated citrons. Subsequently, with the development of a double electrophoresis system (sequential polyacrylamide gel electrophoresis, SPAGE), a number of circular RNAs with faster migration than CEVd were consistently identified in field isolates, and their viroid nature established by infectivity assays on Etrog citron $(11,12)$. Five viroids were initially characterized taking into consideration their electrophoretic migration in 5\% sPAGE, sequence similarity determined by molecular hybridization against specific cDNA probes and specific symptoms on Etrog citron (12). Further se-

\section{Corresponding author: Núria Duran-Vila, E-mail: nduran@ivia.es}

Current address of N. Murcia: Corporación Colombiana de Investigación Agropecuaria - CORPOICA, Palmira, Colombia.

Current address of S. M. Bani Hashemian: Iran Citrus Research Institute, 46915-335 Ramsar, Iran.

Current address of P. Serra: Instituto de Biología Molecular y Celular de Plantas (UPV-CSIC), Valencia, Spain.

Accepted for publication 12 July 2014.

http://dx.doi.org/10.1094/PDIS-05-14-0457-RE

(C) 2015 The American Phytopathological Society quencing and biological assays confirmed that their molecular and biological properties were consistent with the viroid species concept proposed by the International Committee on Taxonomy of Viruses (ICTV) (www.ictvonline.org/virusTaxonomy.asp). In addition to CEVd, Citrus bent leaf viroid (CBLVd), Hop stunt viroid (HSVd), Citrus dwarfing viroid (CDVd), and Citrus bark cracking viroid $(\mathrm{CBCVd})$ have been recognized as true viroid species $(1,33,34,38)$. More recently, two additional viroids, Citrus viroid VI (CVd-VI) (former Citrus viroid OS) and Citrus viroid V (CVd-V) have also been reported $(23,45,46)$. These two viroids were not included in the present study that was initiated before they were described, and none of the viroid sources used contains CVd-V and/or CVd-VI.

The citrus cachexia disease, also known as xyloporosis, was first described in 1948 as discoloration, gumming, and browning of phloem tissues, wood pitting and bark cracking on Orlando tangelo (C. paradisi Macf. $\times$ C. reticulata Blanco) (9), and was suspected of being caused by a viroid (36). Characterization of citrus viroids other than CEVd led to the identification of specific variants of HSVd, in which a specific 5/6-nucleotide motif located in the Variable (V) domain ("cachexia expression motif") was responsible for its pathogenicity, as the causal agent of the cachexia disease $(35,43,47)$.

Even though viroids had been shown to induce different degrees of dwarfing in certain rootstock/scion combinations $(21,22,29,42)$, the effect of each viroid on field grown trees was not fully evaluated until 2004, when the results of a long-term field assay in which clementine trees grafted on trifoliate orange rootstock inoculated with several viroid sources, were evaluated (48). Furthermore, CDVd was shown to be a suitable choice to control tree size in the high-density plantings of Washington navel sweet orange trees (Citrus sinensis L.) grafted on trifoliate orange rootstock $(50,51)$.

Here we report the results of an assay conducted to evaluate the performance of Washington navel sweet orange grafted on the exocortis sensitive Carrizo citrange $(P$. trifoliata $\times C$. sinensis $)$ rootstock in which we used the same viroid inoculum sources used by Vernière et al. (48). 


\section{Materials and Methods}

Viroid sources. Single viroid sources of CEVd, CBLVd, HSVd, $\mathrm{CDVd}$, and CBCVd were selected from the viroid collection maintained at Instituto Valenciano de Investigaciones Agrarias (IVIA). Each source had been maintained in Etrog citron plants grafted on rough lemon that had been periodically tested to verify that they contained the expected viroid. When this assay was initiated in 1989, only limited information was available regarding the molecular and biological properties of these viroid sources. The information available now and the results of their agronomic characterization on clementine trees grafted on trifoliate orange (48) can be summarized as follows:

CEVd. Two isolates, CEVd-117 (EU872276) and CEVd-129 (AF298178), were chosen because they differed in the intensity of the symptoms induced in citron and Gynura aurantiaca (8). Further sequencing and biological characterization demonstrated that in the sequences of these isolates $(8,20)$, presented in the Pathogenicity $(\mathrm{P})$ and Variable $(\mathrm{V})$ domains, the molecular characteristics of CEVd variants had been classified as class A and class B (severe and mild, respectively) based on their pathogenicity on tomato (52). Their further characterization revealed that hosts had a marked effect on the population of CEVd haplotypes as well as in their response to infection $(7,26)$. In addition, clementine trees grafted on trifoliate orange showed only subtle differences in terms of the symptoms induced by these two CEVd isolates (48).

CBLVd. Two isolates, CVd-Ia (EU872278) and CVd-Ib (GQ260200), were initially selected because they differed in their electrophoretic mobility in sPAGE analysis. Isolate CVd-Ia had been recovered from a field source from Spain, and it was highly homologous to the CBLVd (CVd-Ia) reported by Semancik et al. (42) but contained a set of nucleotide changes clustered in the left of the viroid secondary structure $(16,19)$. Isolate CVd-Ib (kindly provided by J. S. Semancik, University of California, Riverside) was similar to the type strain of CBLVd (4).

HSVd. Isolate CVd-IIa (AF213503) had been biologically characterized as a non-cachexia-inducing variant, and sequencing demostrated that it lacked the "cachexia expression motif" in the V domain of the viroid secondary structure $(31,47)$. Isolates CVd-IIb (AF213488) and CVd-IIc (AF213492) had been characterized as cachexia inducing variants, and sequencing demostrated that they contained the "cachexia expression motif" $(31,47)$.

CDVd. Isolates CVd-IIIa (S76452) and CV-IIIb (AF184147) (kindly provided by J. S. Semancik, University of California, Riverside) were isolated from California and differed in 11 nucleotide changes (34). CVd-IIIc (AF184149) and CVd-IIId (EU934019) were selected from Spain and characterized as distinct variants of CDVd (16,27).

$C B C V d$. The single isolate of CBCVd (GQ60216) (kindly provided by J. S. Semancik, University of California, Riverside) was from California, and it had been characterized to the type CBCVd strain (17).

Plant materials and inoculation. In June 1989, 1-year-old Washington navel trees grafted on Carrizo citrange were graftinoculated with one of these 12 viroid isolates (six plants per viroid treatment and six noninoculated controls). The following year the trees were transplanted in a randomized block arrangement in a calcareous, alkaline ( $\mathrm{pH}$ around 8.0), sandy-loam soil. The field
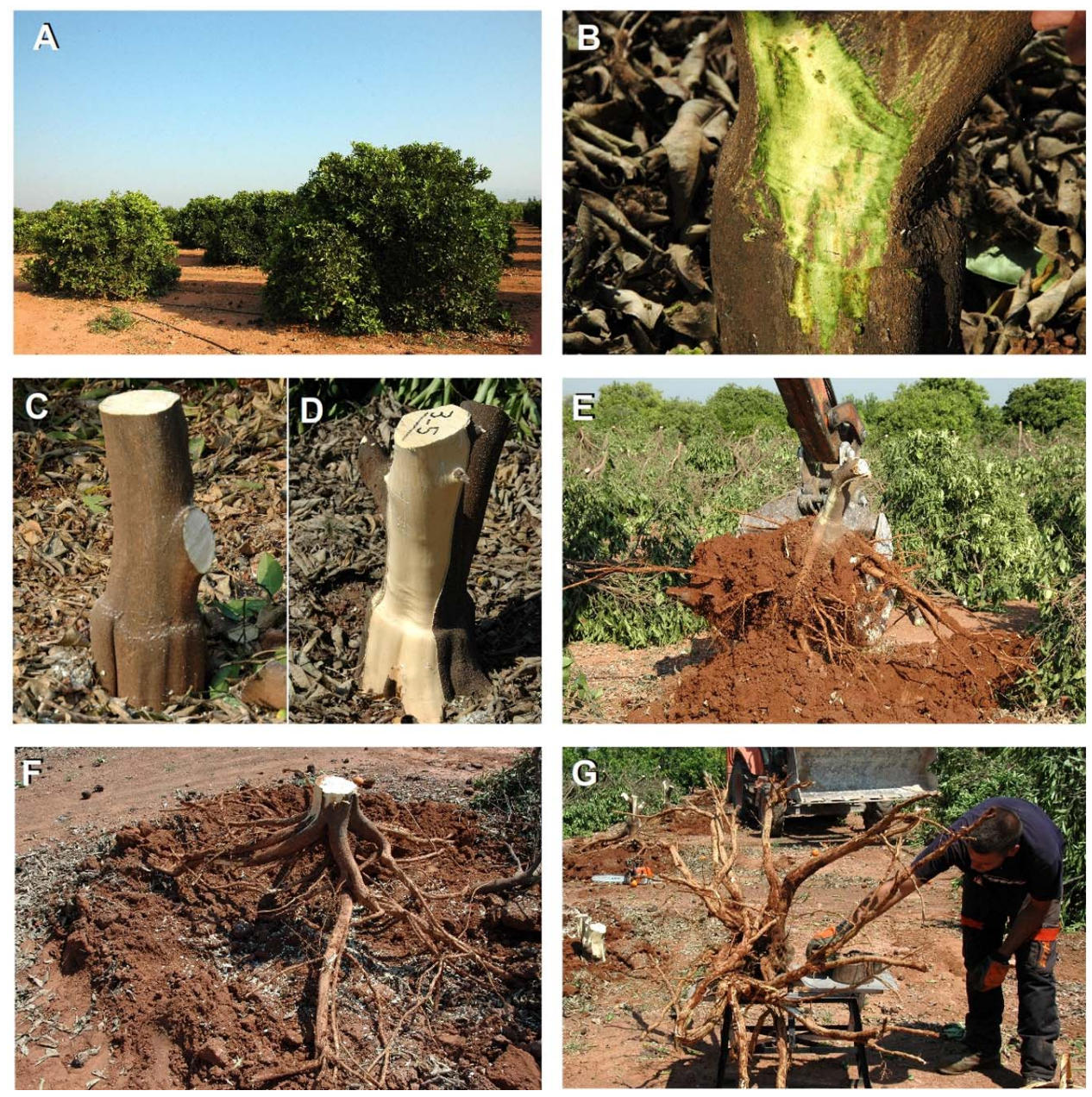

Fig. 1. Field plot of Washington navel trees grafted on Carrizo citrange graft-inoculated with 12 viroid isolates. A, Aspect of the trees when the experiment was terminated. B, Trunk in which the bark had been scraped to show the presence of pitting and gumming symptoms. C, Trees decapitated $50 \mathrm{~cm}$ above the bud-union. D, Trees in which the bark of the stumps had been partially removed for a final evaluation of symptoms on the bark and the wood above and below the bud union. E, Stumps being pulled away from the soil. F, Stumps from which the remaining trunk had been cut away. G, Measuring the fresh weight of the root system. 
plot was located at the Instituto Valenciano de Investigaciones Agrarias (IVIA), Moncada (Valencia, Spain) on the east coast of Spain (Fig. 1A).

The trees were subjected to the standard pruning and harvesting operations of the region. In order to shape the canopy of the trees, two major prunings were performed in 1991 and 1993, and suckers were removed in all subsequent years. Tools were disinfested with a commercial sodium hypochlorite solution $(4 \%)$ between trees. In 2006-2007, all the trees were indexed to verify that they were actually infected with the respective viroid isolates and that the noninoculated controls had remained viroid-free.
Viroid indexing. Bark (5 g) stripped from young shoots was powdered in liquid nitrogen and homogenized in $5 \mathrm{ml}$ of extraction buffer $(0.4 \mathrm{M}$ Tris-HCl, $\mathrm{pH} 8.9 ; 1 \%$ (wt/vol) sodium dodecyl sulfate (SDS); $5 \mathrm{mM}$ EDTA, $\mathrm{pH} 7.0 ; 4 \%$ (vol/vol) 2-mercaptoethanol); and $15 \mathrm{ml}$ of water-saturated phenol. The total nucleic acids were partitioned in $2 \mathrm{M} \mathrm{LiCl}$, and the soluble fraction was concentrated by ethanol precipitation and resuspended in $300 \mu \mathrm{l}$ of TKM buffer (10 mM Tris- $\mathrm{HCl} ; 10 \mathrm{mM} \mathrm{KCl} ; 0.1 \mathrm{mM} \mathrm{MgCl}$, $\mathrm{pH}$ 7.4) (41). Aliquots of these nucleic acid preparations were analyzed by northern blot hybridization as described by Murcia et al. (28). Briefly, the RNAs separated in 5\% PAGE (60 mA, $2 \mathrm{~h})$ were

Table 1. Symptoms observed on viroid-infected Washington navel orange trees grafted on citrange Carrizo

\begin{tabular}{|c|c|c|c|c|c|c|}
\hline \multicolumn{2}{|c|}{ Treatment } & \multirow{2}{*}{$\begin{array}{l}\text { Bark scaling } \\
\text { No. trees }^{\mathrm{a}}\end{array}$} & \multicolumn{2}{|c|}{ Bark cracking } & \multirow{2}{*}{$\frac{\text { Pegs }}{\text { No. trees }^{\mathrm{a}}}$} & \multirow{2}{*}{$\begin{array}{c}\text { Gummy pits } \\
\text { No. trees }^{\mathrm{a}}\end{array}$} \\
\hline Viroid & Isolate & & Intensity & No. trees ${ }^{\mathrm{a}}$ & & \\
\hline Control & & $0 / 6$ & Mild & $6 / 6$ & $0 / 6$ & $0 / 6$ \\
\hline CEVd & $\begin{array}{l}\text { CEVd-117 } \\
\text { CEVd-129 }\end{array}$ & $\begin{array}{l}0 / 6 \\
0 / 6\end{array}$ & $\stackrel{-}{\text { Mild }}$ & $\begin{array}{l}0 / 6 \\
6 / 6\end{array}$ & $\begin{array}{l}1 / 6 \\
1 / 6\end{array}$ & $\begin{array}{l}0 / 6 \\
1 / 6\end{array}$ \\
\hline CBLVd & $\begin{array}{l}\text { CBLVd-Ia } \\
\text { CBLVd-Ib }\end{array}$ & $\begin{array}{l}0 / 6 \\
0 / 6\end{array}$ & - & $\begin{array}{l}0 / 6 \\
0 / 6\end{array}$ & $\begin{array}{l}0 / 6 \\
0 / 6\end{array}$ & $\begin{array}{l}3 / 6 \\
2 / 6\end{array}$ \\
\hline HSVd & $\begin{array}{l}\text { HSVd-IIa } \\
\text { HSVd-IIb } \\
\text { HSVd-IIc }\end{array}$ & $\begin{array}{l}0 / 6 \\
0 / 6 \\
0 / 6\end{array}$ & $\begin{array}{c}- \\
\overline{-} \\
\text { Mild }\end{array}$ & $\begin{array}{l}0 / 6 \\
0 / 6 \\
1 / 6\end{array}$ & $\begin{array}{l}1 / 6 \\
1 / 6 \\
0 / 6\end{array}$ & $\begin{array}{l}3 / 6 \\
1 / 6 \\
2 / 6\end{array}$ \\
\hline CDVd & $\begin{array}{l}\text { CDVd-IIIa } \\
\text { CDVd-IIIb } \\
\text { CDVd-IIIc } \\
\text { CDVd-IIId }\end{array}$ & $\begin{array}{l}0 / 6 \\
0 / 6 \\
0 / 6 \\
0 / 6\end{array}$ & $\begin{array}{l}\text { Mild } \\
- \\
- \\
-\end{array}$ & $\begin{array}{l}2 / 6 \\
0 / 6 \\
0 / 6 \\
0 / 6\end{array}$ & $\begin{array}{l}1 / 6 \\
0 / 6 \\
0 / 6 \\
1 / 6\end{array}$ & $\begin{array}{l}2 / 6 \\
0 / 6 \\
1 / 6 \\
1 / 6\end{array}$ \\
\hline $\mathrm{CBCVd}$ & CBCVd & $0 / 6$ & Severe & $6 / 6$ & $0 / 6$ & $0 / 6$ \\
\hline
\end{tabular}

a Number of trees presenting symptoms over the total number of trees.
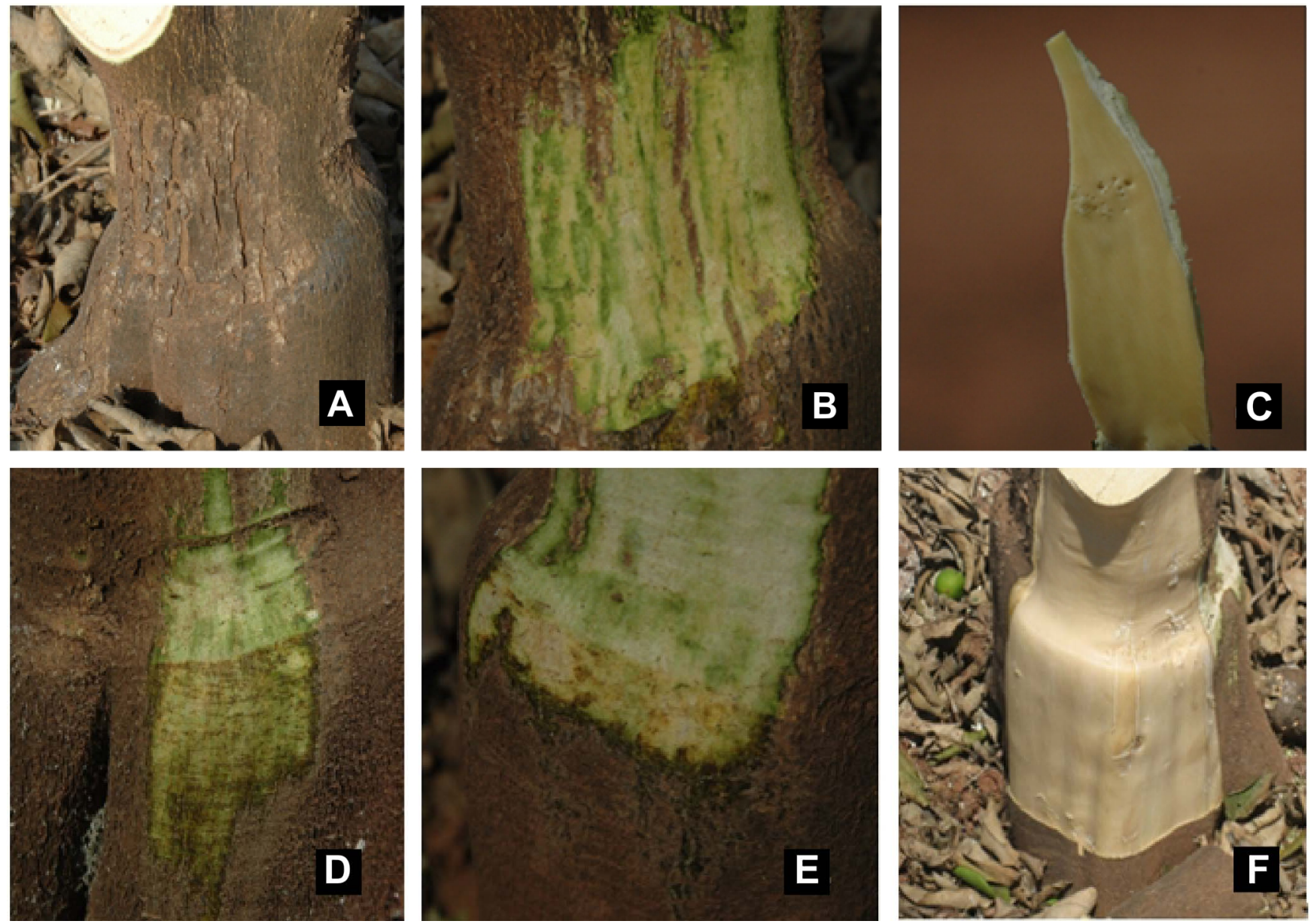

Fig. 2. A, Unspecific bark cracking extending from the rootstock to the scion. B, Green streaks observed in the wood after removing the bark. C, Small pits in the cambial site of the bark. D and $\mathrm{E}$, Horizontal streaks of pits containing gum pockets. F, Unaffected wood. 

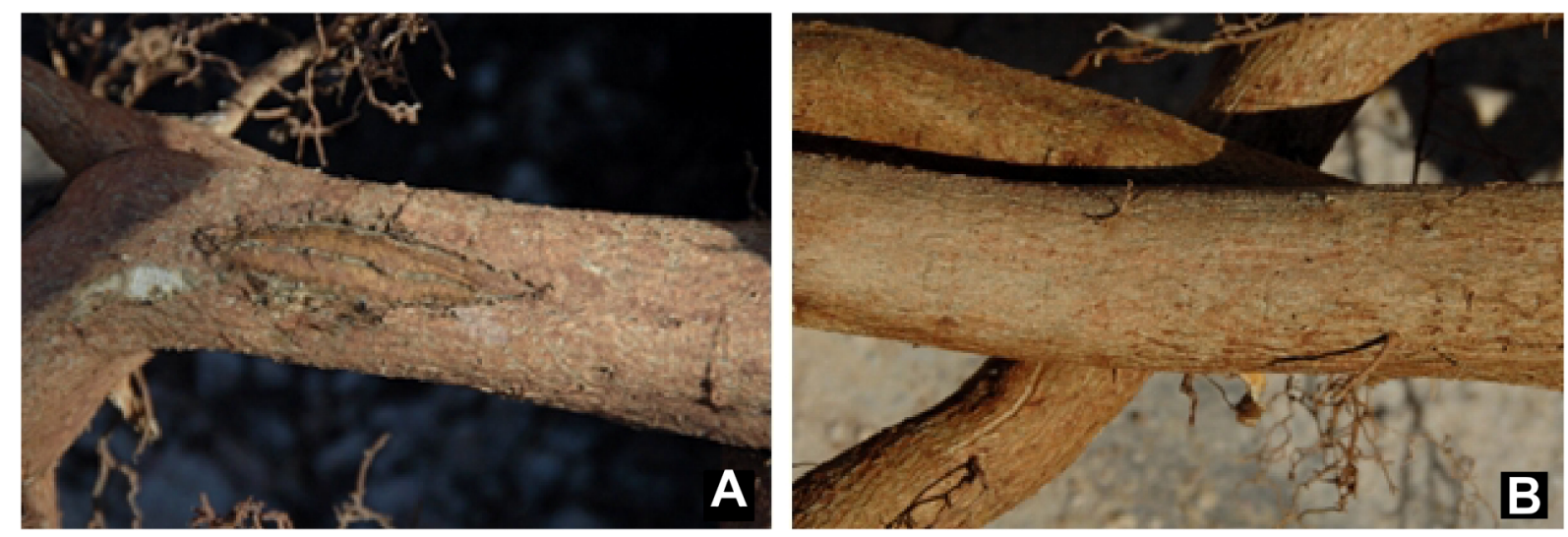

Fig. 3. A, Lesions observed in the roots of trees infected with Citrus exocortis viroid (CEVd)-117. B, Roots of noninfected controls.

Table 2. Vegetative growth parameters of viroid (species and isolates) infected Washington navel sweet orange trees grafted on citrange Carrizo

\begin{tabular}{|c|c|c|c|c|c|c|c|c|}
\hline \multirow[b]{2}{*}{ Treatment } & \multicolumn{2}{|c|}{ Tree height (m) } & \multicolumn{2}{|c|}{ Rootstock circumference $(\mathbf{c m})$} & \multicolumn{2}{|c|}{ Scion circumference $(\mathrm{cm})$} & \multicolumn{2}{|c|}{ Canopy volume $\left(\mathbf{m}^{3}\right)$} \\
\hline & Mean & SE & Mean & SE & Mean & SE & Mean & SE \\
\hline \multicolumn{9}{|l|}{ Viroid species } \\
\hline Control & 2.17 & 0.095 & 51.59 & 2.985 & 41.55 & 2.956 & 5.69 & 0.487 \\
\hline CEVd & 1.89 & 0.076 & 49.72 & 2.516 & 39.46 & 2.244 & 4.44 & 0.349 \\
\hline CBLVd & 2.21 & 0.076 & 54.18 & 2.482 & 42.02 & 2.192 & 5.81 & 0.349 \\
\hline HSVd & 2.13 & 0.069 & 54.13 & 2.482 & 44.19 & 2.086 & 5.56 & 0.289 \\
\hline CDVd & 1.90 & 0.064 & 50.13 & 2.370 & 38.69 & 1.964 & 4.70 & 0.259 \\
\hline CBCVd & 1.64 & 0.095 & 46.76 & 3.234 & 40.67 & 3.316 & 3.60 & 0.486 \\
\hline \multicolumn{9}{|l|}{ Viroid isolates } \\
\hline Control & 2.16 & 0.096 & 51.57 & 2.993 & 41.55 & 2.956 & 5.69 & 0.487 \\
\hline CEVd-117 & 1.84 & 0.096 & 49.91 & 3.236 & 40.92 & 3.316 & 4.15 & 0.487 \\
\hline CEVd-129 & 1.94 & 0.096 & 49.50 & 2.788 & 38.00 & 2.669 & 4.72 & 0.487 \\
\hline CBLVd-Ia & 2.14 & 0.096 & 54.35 & 2.969 & 42.88 & 2.942 & 5.73 & 0.487 \\
\hline CBLVd-Ib & 2.28 & 0.096 & 54.75 & 2.993 & 41.15 & 2.956 & 5.90 & 0.487 \\
\hline HSVd-IIa & 2.14 & 0.096 & 49.17 & 2.993 & 40.55 & 2.956 & 5.28 & 0.487 \\
\hline HSVd-IIb & 2.28 & 0.096 & 58.12 & 3.596 & 47.56 & 3.818 & 5.25 & 0.487 \\
\hline HSVd-IIc & 1.84 & 0.096 & 54.95 & 2.969 & 44.48 & 2.942 & 6.14 & 0.487 \\
\hline CDVd-IIIa & 1.86 & 0.096 & 50.87 & 2.993 & 42.25 & 2.956 & 4.68 & 0.487 \\
\hline CDVd-IIIb & 1.92 & 0.096 & 54.01 & 3.600 & 36.40 & 3.815 & 4.77 & 0.487 \\
\hline CDVd-IIIc & 1.90 & 0.104 & 48.30 & 3.233 & 35.22 & 3.303 & 4.49 & 0.534 \\
\hline CDVd-IIId & 1.90 & 0.096 & 46.90 & 3.236 & 40.92 & 3.316 & 4.87 & 0.487 \\
\hline CBCVd & 1.63 & 0.096 & 46.65 & 3.236 & 40.67 & 3.316 & 3.60 & 0.487 \\
\hline
\end{tabular}

$P$ values obtained when comparing data of viroid-infected treatments with the noninoculated controls $(P$ values lower than 0.05 are shown shaded).

\begin{tabular}{|c|c|c|c|c|}
\hline & Tree height (m) & Rootstock circumference $(\mathrm{cm})$ & Scion circumference $(\mathrm{cm})$ & Canopy volume $\left(\mathrm{m}^{3}\right)$ \\
\hline \multicolumn{5}{|l|}{ Viroid species } \\
\hline Block & 0.124 & 0.119 & 0.303 & \\
\hline Block*Viroid & 0.357 & 0.327 & & 0.265 \\
\hline Year & $<0.0001$ & - & - & $<0.0001$ \\
\hline Viroid & $<0.0001$ & 0.105 & 0.309 & 0.001 \\
\hline Year*Viroid & 0.846 & - & - & 0.062 \\
\hline Control vs. CEVd & 0.037 & 0.919 & 0.934 & 0.126 \\
\hline Control vs. CBLVd & 0.986 & 0.801 & 0.999 & 0.999 \\
\hline Control vs. HSVd & 0.991 & 0.798 & 0.838 & 0.998 \\
\hline Control vs. CDVd & 0.028 & 0.967 & 0.775 & 0.226 \\
\hline Control vs. CBCVd & 0.0002 & 0.453 & 0.999 & 0.013 \\
\hline \multicolumn{5}{|l|}{ Viroid isolates } \\
\hline Block & 0.108 & 0.114 & 0.303 & \\
\hline Year & $<0.0001$ & - & - & $<0.0001$ \\
\hline Isolate & $<0.0001$ & 0.105 & 0.519 & 0.019 \\
\hline Year*Isolate & 0.206 & - & - & 0.291 \\
\hline Control vs. CEVd-117 & 0.069 & 0.999 & 1.000 & 0.203 \\
\hline Control vs. CEVd-129 & 0.358 & 0.998 & 0.965 & 0.722 \\
\hline Control vs. CBLVd-Ia & 1.000 & 0.998 & 1.000 & 1.000 \\
\hline Control vs. CBLVd-Ib & 0.962 & 0.995 & 1.000 & 1.000 \\
\hline Control vs. HSVd-IIa & 0.867 & 0.995 & 1.000 & 0.999 \\
\hline Control vs. HSVd-IIb & 0.999 & 0.530 & 0.798 & 0.998 \\
\hline Control vs. HSVd-IIc & 0.992 & 0.954 & 0.995 & 0.998 \\
\hline Control vs. CDVd-IIIa & 0.097 & 1.000 & 1.000 & 0.675 \\
\hline Control vs. CDVd-IIIb & 0.291 & 0.998 & 0.902 & 0.775 \\
\hline Control vs. CDVd-IIIc & 0.259 & 0.971 & 0.647 & 0.529 \\
\hline Control vs. CDVd-IIId & 0.217 & 0.795 & 1.000 & 0.859 \\
\hline Control vs. CBCVd & 0.0004 & 0.747 & 1.000 & 0.031 \\
\hline
\end{tabular}


electroblotted ( $400 \mathrm{~mA}$ for $2 \mathrm{~h}$ ) from the gel to Nylon membranes, immobilized by UV cross-linking, and hybridized with viroidspecific DIG-labeled DNA probes generated by polymerase chain reaction (PCR) using as templates plasmids containing full-length viroid DNA inserts (30). Prehybridization and hybridization were performed in $50 \%$ formamide, and the DIG-labeled hybrids were detected with an anti-DIG-alkaline phosphatase conjugate (Fab fragments) and visualized by autoradiography with the chemiluminescence substrate CSPD (Roche).

Symptom evaluation. Bark symptoms (scaling and cracking) were evaluated when the experiment was terminated in 2008 (Fig. 1A). The bark was scraped above and below the bud-union to verify the presence of pitting and gumming symptoms (Fig. 1B). The trees were decapitated $50 \mathrm{~cm}$ above the bud-union (Fig. 1C), and the bark of the stumps was removed for a final evaluation of symptoms on the bark and the wood above and below the budunion (Fig. 1D). Finally, the stumps were pulled out of the soil (Fig. 1E) for a final evaluation of symptoms in the roots. After cutting away the remaining trunk (Fig. 1F), the fresh weight of the root system was measured after removing the soil that was attached to the roots (Fig. 1G).

Tree growth and fruit yield. Tree height, trunk circumferences of the scion and the rootstock $(10 \mathrm{~cm}$ above and below the bud line) were measured in 2004 and 2007. The canopy volume was estimated as $V c=4 / 3 \pi R^{3}$ (R being the radius of the canopy calculated from the canopy height and two perpendicular width measurements). Fruits were harvested manually, and fruit yield data were recorded in 2004, 2006, and 2007.

Fruit quality. From October 2005 to February 2006, the evolution of the color and size (length and diameter) of 10 randomly collected fruits from each tree was recorded at monthly intervals. Color index was determined using a colorimeter (Minolta CR-300) (24) taking into consideration the average of three independent measurements made at the equatorial zone of the fruit. During the same period, measurements of fruit length and diameter were also recorded from the same sampled fruits.

External fruit quality parameters were determined using fruit samples (10 fruits per tree) collected during the 2007 harvest and were recorded as follows: (i) fruit shape determined as the average of the diameter/length values; (ii) average of rind thickness measured at the equatorial zone using a digital caliper; (iii) bulk weight of the 10 fruits of each sample; (iv) bulk fruit size (volume) measured using the water displacement method; and (v) fruit density calculated as quotient between weight and fruit volume.

Internal fruit quality parameters were determined using fruit samples (10 fruits per tree) collected during the 2007 harvest and were recorded as follows: (i) volume of juice extracted from the 10 fruit samples using a squeezer (Zumonat C40) that operates at 14 $\mathrm{kg} / \mathrm{cm}^{2}$ and contains a series of filters retaining the large particles; (ii) juice density measured with a densitometer (Proton 1000-1100) calibrated at $15^{\circ} \mathrm{C}$; (iii) soluble solids measured with a refractometer (Atago PR-101); (iv) total acidity measured by titration of $100 \mathrm{ml}$ of juice with $\mathrm{NaOH} 0.1 \mathrm{~N}$ and correcting the volume of $\mathrm{NaOH}(\times 1.28)$ to obtain the corresponding percentage $(\%)$ of citric acid; and (v) maturity index calculated as the quotient of percentage of soluble solids and acidity percentage.

Statistical analysis. The effect of viroid infection and the effect of viroid isolates was performed by repeated measures ANOVA. Comparisons with the control were done with the Dunnett test. Analysis was performed using the Statgraphics Plus 5.1 software.

\section{Results}

Symptoms induced by viroid infection. No bark scaling symptoms were observed in any of the treatments (Table 1). Unspecific mild bark cracking symptoms were observed in several treatments, including the viroid-free controls. This mild bark cracking affected the rootstock as well as the scion (Fig. 2A). Severe bark cracking symptoms were consistently found in the rootstock of all the trees infected with CBCVd (Table 1). As reported earlier in the case of trees grafted in trifoliate orange (48), severe cracking was more perceptible by observing the characteristic green streaks easily observable after scraping the bark (Fig. 2B).

After removing the bark, small pits were observed on the cambial side of the bark of Carrizo citrange rootstock (Fig. 2C) that were not associated with any of the treatments. Horizontal streaks of pits containing gum pockets (Fig. 2D and E) somewhat similar to the "wood pitting", "gum pocket", and "gummy pitting" disorders described in Argentina, South Africa, and Australia, respectively $(14,15,18,25,40)$, were also observed in a few trees of several treatments. When the experiment was terminated and the trees were pulled out, small lesions were observed in the roots of CEVd-infected trees (Fig. 3).

Effect of viroid infection on tree size and fruit harvest. Vegetative growth. As shown in Table 2, vegetative growth was affected by viroid infection with height and canopy volume being significantly reduced. Mean parameters (height, rootstock, and scion circumferences and canopy volume) of trees infected with

Table 3. Root weight of viroid (species and isolates) infected Washington navel sweet orange trees grafted on citrange Carrizo

\begin{tabular}{lll}
\hline & \multicolumn{2}{c}{ Rootstock weight (kg) } \\
\cline { 2 - 3 } Treatment & Mean & SE \\
\hline Viroid species & \\
Control & 15.67 & 3.640 \\
CEVd & 13.27 & 2.674 \\
CBLVd & 17.18 & 2.674 \\
HSVd & 19.53 & 2.261 \\
CDVd & 14.47 & 2.066 \\
CBCVd & 11.53 & 3.640 \\
Viroid isolates & & \\
Control & 15.67 & 3.645 \\
CEVd-117 & 12.37 & 3.645 \\
CEVd-129 & 14.17 & 3.645 \\
CBLVd-Ia & 16.92 & 3.645 \\
CBLVd-Ib & 17.42 & 3.645 \\
HSVd-IIa & 25.84 & 3.645 \\
HSVd-IIb & 16.17 & 3.645 \\
HSVd-IIc & 16.59 & 3.645 \\
CDVd-IIIa & 13.67 & 3.645 \\
CDVd-IIIb & 15.50 & 3.645 \\
CDVd-IIIc & 15.30 & 3.992 \\
CDVd-IIId & 13.45 & 3.645 \\
CBCVd & 11.53 & 3.645 \\
\hline P & & \\
\hline
\end{tabular}

$P$ values obtained when comparing data of viroid-infected treatments with the noninoculated controls.

\begin{tabular}{lc}
\hline & Rootstock weight $(\mathbf{k g})$ \\
\hline Viroid species & \\
Block & \\
Block*Viroid & 0.2599 \\
Viroid & 0.3624 \\
Control vs. CEVd & 0.9625 \\
Control vs. CBLVd & 0.9950 \\
Control vs. HSVd & 0.7768 \\
Control vs. CDVd & 0.9975 \\
Control vs. CBCVd & 0.8398 \\
Viroid isolates & \\
Block & \\
Viroid isolate & 0.5230 \\
Control vs. CEVd-117 & 0.9983 \\
Control vs. CEVd-129 & 1.0000 \\
Control vs. CBLVd-Ia & 1.0000 \\
Control vs. CBLVd-Ib & 1.0000 \\
Control vs. HSVd-IIa & 0.3280 \\
Control vs. HSVd-IIb & 1.0000 \\
Control vs. HSVd-IIc & 1.0000 \\
Control vs. CDVd-IIIa & 1.0000 \\
Control vs. CDVd-IIIb & 1.0000 \\
Control vs. CDVd-IIIc & 1.0000 \\
Control vs. CDVd-IIId & 1.0000 \\
Control vs. CBCVd & 0.9890 \\
\hline
\end{tabular}


CEVd, CDVd, or CBCVd were lower than those of the noninoculated control with $\mathrm{CBCVd}$ having the strongest effect. Rootstock and scion circumferences were only slightly affected. There was no significant block effect, and the interaction year*viroid was not significant, indicating that the observed effects were due to viroid infection. Comparison of vegetative growth parameters of each viroid isolate (Table 2), although not statistically different, indicated the following: (i) CEVd-117 had a stronger effect than CEVd-129 on tree height, scion circumference, and canopy volume; (ii) CBLVd-Ia had a stronger effect than CBLVd-Ib on tree height and canopy volume; (iii) HSVd-IIc had a stronger effect on tree height, whereas HSV-IIa had stronger effect on rootstock and scion circumferences; and (iv) CDVd showed variable effects.
When the experiment was terminated, the fresh weight of the roots was evaluated. As shown in Table 3, viroid infection did not affect significantly this parameter. The mean fresh weights of trees infected with CEVd or with CBCVd were smaller than those of the noninfected controls, but the differences were not statistically significant. There was no significant block effect, indicating that the observed effects were due to viroid infection. When data from each isolate were compared (Table 3), the major deviations from the noninoculated controls were found in the case of trees infected with CBCVd, with the severe CEVd isolate (CEVd-117) and with two of the four CDVd isolates tested, but the differences were not statistically significant. Unexpectedly, the mean value of one of the HSVd isolates (HSVd-IIa) was higher than that of

Table 4. Fruit yields of viroid (species and isolates) infected Washington navel sweet orange trees grafted on citrange Carrizo

\begin{tabular}{|c|c|c|c|c|c|c|}
\hline \multirow[b]{2}{*}{ Treatment } & \multicolumn{2}{|c|}{ Yield /canopy volume } & \multicolumn{2}{|c|}{ Annual yield $(\mathbf{k g})^{\mathbf{b}}$} & \multicolumn{2}{|c|}{ Cumulative yield (kg)c } \\
\hline & Mean & SE & Mean & SE & Mean & SE \\
\hline \multicolumn{7}{|l|}{ Viroid species } \\
\hline Control & 15.79 & 1.533 & 66.42 & 7.062 & 199.25 & 21.371 \\
\hline CEVd & 18.10 & 1.122 & 62.40 & 6.235 & 187.21 & 18.916 \\
\hline CBLVd & 14.69 & 1.122 & 68.61 & 6.235 & 205.83 & 18.916 \\
\hline HSVd & 16.66 & 0.946 & 68.31 & 5.934 & 204.92 & 18.022 \\
\hline CDVd & 18.14 & 0.863 & 63.06 & 5.788 & 190.93 & 17.647 \\
\hline CBCVd & 20.28 & 1.532 & 51.00 & 7.062 & 153.00 & 21.371 \\
\hline \multicolumn{7}{|l|}{ Viroid isolates } \\
\hline Control & 15.79 & 1.524 & 66.42 & 7.208 & 199.25 & 21.864 \\
\hline CEVd-117 & 18.98 & 1.524 & 59.58 & 7.208 & 178.75 & 21.864 \\
\hline CEVd-129 & 17.22 & 1.524 & 65.22 & 7.208 & 195.67 & 21.864 \\
\hline CBLVd-Ia & 14.75 & 1.524 & 66.83 & 7.208 & 200.50 & 21.864 \\
\hline CBLVd-Ib & 14.63 & 1.524 & 70.39 & 7.208 & 211.17 & 21.864 \\
\hline HSVd-IIa & 15.64 & 1.524 & 66.03 & 7.208 & 198.08 & 21.864 \\
\hline HSVd-IIb & 20.65 & 1.524 & 71.33 & 7.208 & 214.00 & 21.864 \\
\hline HSVd-IIc & 13.69 & 1.524 & 67.56 & 7.208 & 202.67 & 21.864 \\
\hline CDVd-IIIa & 17.81 & 1.524 & 62.86 & 7.208 & 188.58 & 21.864 \\
\hline CDVd-IIIb & 18.49 & 1.524 & 64.06 & 7.208 & 192.17 & 21.864 \\
\hline CDVd-IIIc & 19.25 & 1.670 & 63.19 & 7.359 & 194.34 & 23.172 \\
\hline CDVd-IIId & 17.07 & 1.524 & 61.56 & 7.208 & 184.67 & 21.864 \\
\hline CBCVd & 20.28 & 1.524 & 51.00 & 7.208 & 153.00 & 21.864 \\
\hline \multicolumn{7}{|c|}{$P$ values obtained when comparing data of viroid-infected treatments with the noninoculated controls $(P$ values lower than 0.05 are shown shaded). } \\
\hline & \multicolumn{2}{|c|}{ Yield /canopy volume } & \multicolumn{2}{|c|}{ Annual yield (kg) } & \multicolumn{2}{|c|}{ Cumulative yield (kg) } \\
\hline \multicolumn{7}{|l|}{ Viroid species } \\
\hline Block & \multicolumn{2}{|c|}{0.256} & \multicolumn{2}{|c|}{0.094} & \multicolumn{2}{|c|}{0.092} \\
\hline Block*Viroid & \multicolumn{2}{|c|}{0.252} & \multicolumn{2}{|c|}{0.036} & \multicolumn{2}{|c|}{0.057} \\
\hline Year & \multicolumn{2}{|c|}{$<0.0001$} & \multicolumn{2}{|c|}{$<0.0001$} & & \\
\hline Viroid & & & & & & \\
\hline Year*Viroid & & & & & & \\
\hline Control vs. CEVd & & & & & & \\
\hline Control vs. CBLVd & & & & & & \\
\hline Control vs. HSVd & & & & & & \\
\hline Control vs. CDVd & & & & & & \\
\hline Control vs. CBCVd & & & & & & \\
\hline Viroid isolates & & & & & & \\
\hline Block & & & & & & \\
\hline Year & & & & & & \\
\hline Isolate & & & & & & \\
\hline Year*Isolate & & & & & & \\
\hline Control vs. CEVd-117 & & & & & & \\
\hline Control vs. CEVd-129 & & & & & & \\
\hline Control vs. CBLVd-Ia & & & & & & \\
\hline Control vs. CBLVd-Ib & & & & & & \\
\hline Control vs. HSVd-IIa & & & & & & \\
\hline Control vs. HSVd-IIb & & & & & & \\
\hline Control vs. HSVd-IIc & & & & & & \\
\hline Control vs. CDVd-IIIa & & & & & & \\
\hline Control vs. CDVd-IIIb & & & & & & \\
\hline Control vs. CDVd-IIIc & & & & & & \\
\hline Control vs. CDVd-IIId & & & & & & \\
\hline Control vs. CBCVd & & & & & & \\
\hline
\end{tabular}

a Average of data collected in years 2004 and 2007.

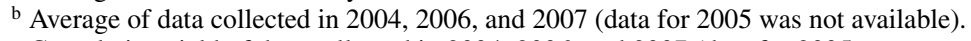

${ }^{c}$ Cumulative yield of data collected in 2004, 2006, and 2007 (data for 2005 was not available). 
the noninoculated controls, but the difference was not statistically significant.

Fruit harvest. As shown in Table 4, fruit harvest parameters were affected by annual conditions as indicated by the "year" significance $(P<0.0001)$. No major differences in annual and cumulative yields were found between viroid-infected trees and the noninoculated controls, but an interesting effect was identified in terms of tree productivity increase (yield/canopy volume) $(P=$ 0.043 ), which appears to be modulated by annual conditions as shown by the interaction "year*viroid" $(P=0.029)$. It must be mentioned that $\mathrm{CBCVd}$ induced the highest productivity (yield/ canopy volume) in spite of the relatively small annual and cumulative yields which were compensated by the small canopy (Table 2). There were no significant block effects, and the interaction year*viroid was not significant, indicating that the observed effects were due to viroid infection.

Fruit characteristics. Only slight differences were found in color index during the fruit-ripening period, but the values became es- sentially identical at harvest time (Table 5). No statistical differences were found when the values of viroid-infected trees were compared with those of the noninoculated control or when the values of the various isolates were compared (Table 5). Slight differences were observed in some of the fruit parameters measured, which became more obvious at harvest time (Table 6). The results suggest that the fruits of HSVd-infected trees were slightly smaller (height, $P=0.032$; diameter, $P=0.086$ ) than those of the noninfected controls. When the fruit length and diameter of trees infected with each isolate were compared, no significant differences were found (Table 6), but the results suggest that the fruits of trees infected with isolate HSVd-IIc were somewhat smaller.

Viroid infection affected external fruit quality parameters by reducing fruit length $(P=0.033)$, size $(P=0.041)$, and density with no effect on fruit shape (diameter/length), rind thickness, and fruit density (Table 7). It should be mentioned that, although the differences were not statistically significant, HSVd affected fruit sizes that are smaller than the controls, and CBCVd caused an

Table 5. Color evolution of fruits from viroid (species and isolates) infected Washington navel sweet orange trees grafted on Carrizo citrange

\begin{tabular}{|c|c|c|c|c|c|c|c|c|c|c|c|c|}
\hline \multirow[b]{2}{*}{ Treatment } & \multicolumn{2}{|c|}{ Color $1^{\mathrm{a}}$} & \multicolumn{2}{|c|}{ Color 2} & \multicolumn{2}{|c|}{ Color 3} & \multicolumn{2}{|c|}{ Color 4} & \multicolumn{2}{|c|}{ Color 5} & \multicolumn{2}{|c|}{ Color 6} \\
\hline & Mean & SE & Mean & $\mathbf{S E}$ & Mean & SE & Mean & $\mathbf{S E}$ & Mean & SE & Mean & SE \\
\hline \multicolumn{13}{|l|}{ Viroid species } \\
\hline Control & -11.03 & 0.719 & 0.81 & 1.165 & 7.99 & 0.676 & 10.02 & 0.406 & 12.04 & 0.317 & 14.57 & 0.504 \\
\hline CEVd & -10.88 & 0.560 & 0.31 & 1.016 & 7.30 & 0.602 & 10.36 & 0.316 & 11.95 & 0.241 & 14.49 & 0.367 \\
\hline CBLVd & -10.61 & 0.560 & 0.22 & 1.016 & 7.76 & 0.602 & 9.16 & 0.316 & 12.19 & 0.241 & 14.32 & 0.367 \\
\hline HSVd & -10.84 & 0.496 & -0.17 & 0.962 & 7.38 & 0.574 & 9.77 & 0.280 & 12.04 & 0.209 & 14.47 & 0.308 \\
\hline CDVd & -11.39 & 0.467 & 0.38 & 0.938 & 7.12 & 0.563 & 9.70 & 0.264 & 11.94 & 0.195 & 14.71 & 0.280 \\
\hline $\mathrm{CBCVd}$ & -12.67 & 0.719 & 1.74 & 1.165 & 5.93 & 0.676 & 9.25 & 0.404 & 12.25 & 0.316 & 15.08 & 0.504 \\
\hline \multicolumn{13}{|c|}{ Viroid isolates } \\
\hline Control & -11.03 & 0.713 & 0.81 & 1.162 & 7.99 & 0.629 & 10.03 & 0.405 & 12.04 & 0.317 & 14.57 & 0.504 \\
\hline CEVd-117 & -11.02 & 0.713 & 0.19 & 1.162 & 7.22 & 0.629 & 10.27 & 0.405 & 12.01 & 0.317 & 13.84 & 0.504 \\
\hline CEVd-129 & -10.74 & 0.713 & 0.43 & 1.162 & 7.38 & 0.629 & 10.44 & 0.405 & 11.89 & 0.317 & 15.15 & 0.504 \\
\hline CBLVd-Ia & -10.48 & 0.713 & 0.47 & 1.162 & 7.97 & 0.629 & 8.99 & 0.405 & 12.01 & 0.317 & 14.34 & 0.504 \\
\hline CBLVd-Ib & -10.74 & 0.713 & -0.03 & 1.162 & 7.54 & 0.629 & 9.33 & 0.405 & 12.36 & 0.317 & 14.30 & 0.504 \\
\hline HSVd-IIa & -11.28 & 0.713 & -0.94 & 1.162 & 6.79 & 0.629 & 9.57 & 0.405 & 12.32 & 0.317 & 14.57 & 0.504 \\
\hline HSVd-IIb & -10.39 & 0.713 & 0.44 & 1.162 & 8.23 & 0.629 & 9.97 & 0.405 & 11.91 & 0.317 & 15.06 & 0.504 \\
\hline HSVd-IIc & -10.83 & 0.713 & -0.01 & 1.162 & 7.12 & 0.629 & 9.77 & 0.405 & 11.90 & 0.317 & 13.76 & 0.504 \\
\hline CDVd-IIIa & -11.56 & 0.713 & -0.28 & 1.162 & 6.95 & 0.629 & 9.96 & 0.405 & 12.06 & 0.317 & 14.98 & 0.504 \\
\hline CDVd-IIIb & -11.87 & 0.713 & 0.30 & 1.162 & 6.90 & 0.629 & 9.62 & 0.405 & 11.80 & 0.317 & 14.13 & 0.504 \\
\hline CDVd-IIIc & -10.71 & 0.777 & 0.84 & 1.223 & 7.64 & 0.679 & 9.80 & 0.439 & 12.79 & 0.344 & 14.78 & 0.504 \\
\hline CDVd-IIId & -11.37 & 0.713 & 0.69 & 1.162 & 6.89 & 0.629 & 9.41 & 0.405 & 11.11 & 0.317 & 14.93 & 0.504 \\
\hline $\mathrm{CBCVd}$ & -12.67 & 0.713 & 1.74 & 1.162 & 5.93 & 0.629 & 9.25 & 0.405 & 12.25 & 0.317 & 15.08 & 0.504 \\
\hline
\end{tabular}

$P$ values obtained when comparing data of viroid infected treatments with the noninoculated controls.

\begin{tabular}{|c|c|c|c|c|c|c|}
\hline & Color 1 & Color 2 & Color 3 & Color 4 & Color 5 & Color 6 \\
\hline \multicolumn{7}{|l|}{ Viroid species } \\
\hline Block & 0.164 & 0.072 & 0.129 & 0.110 & 0.134 & 0.242 \\
\hline Block*Viroid & 0.328 & 0.428 & 0.079 & & & \\
\hline Viroid & 0.224 & 0.526 & 0.232 & 0.228 & 0.894 & 0.832 \\
\hline Control vs. CEVd & 0.999 & 0.970 & 0.816 & 0.854 & 0.999 & 0.999 \\
\hline Control vs. CBLVd & 0.968 & 0.944 & 0.998 & 0.166 & 0.984 & 0.983 \\
\hline Control vs. HSVd & 0.999 & 0.684 & 0.865 & 0.940 & 1.000 & 0.999 \\
\hline Control vs. CDVd & 0.978 & 0.979 & 0.628 & 0.840 & 0.997 & 0.999 \\
\hline Control vs. CBCVd & 0.256 & 0.838 & 0.069 & 0.356 & 0.872 & 0.872 \\
\hline \multicolumn{7}{|l|}{ Viroid isolates } \\
\hline Block & 0.158 & 0.071 & 0.106 & 0.110 & 0.134 & 0.242 \\
\hline Block*Isolate & 0.0001 & $<0.0001$ & $<0.0001$ & 0.436 & 0.023 & 0.0170 \\
\hline Isolate & 0.568 & 0.831 & 0.274 & 0.221 & 0.101 & 0.515 \\
\hline Control vs. CEVd-117 & 1.000 & 1.000 & 0.951 & 1.000 & 1.000 & 0.922 \\
\hline Control vs. CEVd-129 & 1.000 & 1.000 & 0.992 & 0.985 & 1.000 & 0.985 \\
\hline Control vs. CBLVd-Ia & 0.999 & 1.000 & 1.000 & 0.302 & 1.000 & 1.000 \\
\hline Control vs. CBLVd-Ib & 1.000 & 0.995 & 1.000 & 0.755 & 0.990 & 1.000 \\
\hline Control vs. HSVd-IIa & 1.000 & 0.646 & 0.633 & 0.980 & 0.997 & 1.000 \\
\hline Control vs. HSVd-IIb & 0.997 & 1.000 & 1.000 & 1.000 & 1.000 & 0.996 \\
\hline Control vs. HSVd-IIc & 1.000 & 0.996 & 0.905 & 1.000 & 1.000 & 0.872 \\
\hline Control vs. CDVd-IIIa & 1.000 & 0.965 & 0.784 & 1.000 & 1.000 & 0.999 \\
\hline Control vs. CDVd-IIIb & 0.977 & 1.000 & 0.738 & 0.991 & 1.000 & 0.998 \\
\hline Control vs. CDVd-IIIc & 1.000 & 1.000 & 1.000 & 1.000 & 0.469 & 1.000 \\
\hline Control vs. CDVd-IIId & 1.000 & 1.000 & 0.727 & 0.860 & 0.194 & 1.000 \\
\hline Control vs. CBCVd & 0.480 & 0.989 & 0.086 & 0.643 & 1.000 & 0.995 \\
\hline
\end{tabular}

${ }^{a}$ Color was evaluated with a random sample of 10 fruits per tree. Data were collected monthly from October until harvesting time. 
increase in fruit size and weight. When quality parameters of fruits from trees infected with each isolate were compared, no significant differences were found (Table 7). As indicated above, the results indicate that the fruits of trees infected with isolate HSVd-IIc were somewhat smaller.

Internal quality parameters of fruits harvested in 2007 are shown in Table 8. Fruits collected from CEVd- or CDVd-infected trees contained less soluble solids, but the differences were not highly significant $(P=0.151$ and $P=0.165$, respectively) with only minor effects on the maturity index. When quality parameters of fruits from trees infected with each isolate were compared, only relevant differences in the content of soluble solids were found in the case of fruits collected from trees infected with one of the CDVd isolates $(\mathrm{CDVd}-\mathrm{IIIc})(P=0.105)$ (Table 8$)$.

\section{Discussion}

The use of Etrog citron as the exocortis indicator for biological indexing purposes revealed a range of symptoms that were erroneously considered as evidence for the existence of different CEVd strains until viroids other than CEVd were identified and shown to induce specific symptoms in this indicator $(11,12)$. Since naturally occurring field isolates contain more than a single viroid, the effect of each viroid on field grown trees was not established until 2004, when the results of a long-term field assay performed with clementine trees grafted on the trifoliate orange rootstock became available (48). Additional long-term field assays also revealed that viroid-induced effects might be attenuated or enhanced when trees were exposed to mixed viroid infections $(49,51)$.

Table 6. Growth of fruits from viroid (species and isolates) infected Washington navel sweet orange trees grafted on Carrizo citrange ${ }^{\text {a }}$

\begin{tabular}{|c|c|c|c|c|c|c|c|c|c|c|c|c|}
\hline \multirow[b]{2}{*}{ Treatment } & \multicolumn{2}{|c|}{ Length 1 (mm) } & \multicolumn{2}{|c|}{ Length 2 (mm) } & \multicolumn{2}{|c|}{ Length 3 (mm) } & \multicolumn{2}{|c|}{ Length 4 (mm) } & \multicolumn{2}{|c|}{ Length 5 (mm) } & \multicolumn{2}{|c|}{ Length $6(\mathrm{~mm})$} \\
\hline & Mean & SE & Mean & SE & Mean & SE & Mean & SE & Mean & SE & Mean & SE \\
\hline \multicolumn{13}{|l|}{ Viroid species } \\
\hline Control & 71.86 & 0.853 & 75.42 & 1.164 & 77.25 & 1.17 & 79.05 & 1.254 & 77.71 & 1.178 & 84.49 & 1.237 \\
\hline CEVd & 71.62 & 0.608 & 75.28 & 0.967 & 77.58 & 0.95 & 76.46 & 1.019 & 78.32 & 0.914 & 82.47 & 0.945 \\
\hline CBLVd & 72.06 & 0.608 & 75.09 & 0.967 & 76.57 & 0.95 & 76.24 & 1.019 & 77.79 & 0.914 & 82.33 & 0.945 \\
\hline HSVd & 71.47 & 0.501 & 74.78 & 0.892 & 76.95 & 0.86 & 76.87 & 0.927 & 78.21 & 0.806 & 80.97 & 0.825 \\
\hline CDVd & 71.87 & 0.449 & 75.66 & 0.859 & 77.04 & 0.82 & 76.80 & 0.886 & 78.13 & 0.758 & 83.14 & 0.769 \\
\hline CBCVd & 72.38 & 0.853 & 76.25 & 1.164 & 79.90 & 1.17 & 79.25 & 1.256 & 77.30 & 1.178 & 84.56 & 1.237 \\
\hline \multicolumn{13}{|l|}{ Viroid isolates } \\
\hline Control & 71.86 & 0.853 & 75.42 & 1.166 & 77.25 & 1.159 & 79.05 & 1.256 & 77.71 & 1.181 & 84.49 & 1.238 \\
\hline CEVd-117 & 72.06 & 0.853 & 75.06 & 1.166 & 77.44 & 1.159 & 76.44 & 1.256 & 76.96 & 1.181 & 82.35 & 1.238 \\
\hline CEVd-129 & 71.17 & 0.853 & 75.50 & 1.166 & 77.72 & 1.159 & 76.49 & 1.256 & 79.68 & 1.181 & 82.59 & 1.238 \\
\hline CBLVd-Ia & 72.53 & 0.853 & 75.68 & 1.166 & 77.23 & 1.159 & 76.43 & 1.256 & 77.55 & 1.181 & 83.15 & 1.238 \\
\hline CBLVd-Ib & 71.58 & 0.853 & 74.50 & 1.166 & 75.91 & 1.159 & 76.05 & 1.256 & 78.02 & 1.181 & 81.51 & 1.238 \\
\hline HSVd-IIa & 71.72 & 0.853 & 74.88 & 1.166 & 77.31 & 1.159 & 77.20 & 1.256 & 79.28 & 1.181 & 81.13 & 1.238 \\
\hline HSVd-IIb & 71.54 & 0.853 & 74.95 & 1.166 & 76.43 & 1.159 & 76.77 & 1.256 & 76.88 & 1.181 & 81.31 & 1.238 \\
\hline HSVd-IIc & 71.16 & 0.853 & 74.50 & 1.166 & 77.11 & 1.159 & 76.64 & 1.256 & 78.47 & 1.181 & 80.47 & 1.238 \\
\hline CDVd -IIIa & 71.12 & 0.853 & 75.02 & 1.166 & 76.24 & 1.159 & 76.83 & 1.256 & 78.22 & 1.181 & 82.47 & 1.238 \\
\hline CDVd -IIIb & 72.01 & 0.853 & 76.26 & 1.166 & 76.81 & 1.159 & 77.11 & 1.256 & 77.89 & 1.181 & 82.37 & 1.238 \\
\hline CDVd -IIIc & 72.22 & 0.934 & 75.48 & 1.264 & 77.66 & 1.269 & 76.55 & 1.348 & 79.07 & 1.294 & 85.05 & 1.344 \\
\hline CDVd -IIId & 72.13 & 0.853 & 75.95 & 1.166 & 77.46 & 1.159 & 76.71 & 1.256 & 77.42 & 1.181 & 82.67 & 1.238 \\
\hline CBCVd & 72.38 & 0.853 & 76.25 & 1.166 & 79.90 & 1.159 & 79.24 & 1.256 & 77.29 & 1.181 & 84.56 & 1.238 \\
\hline
\end{tabular}

$P$ values obtained when comparing data of viroid infected treatments with the noninoculated controls $(P$ values lower than 0.05 are shown shaded).

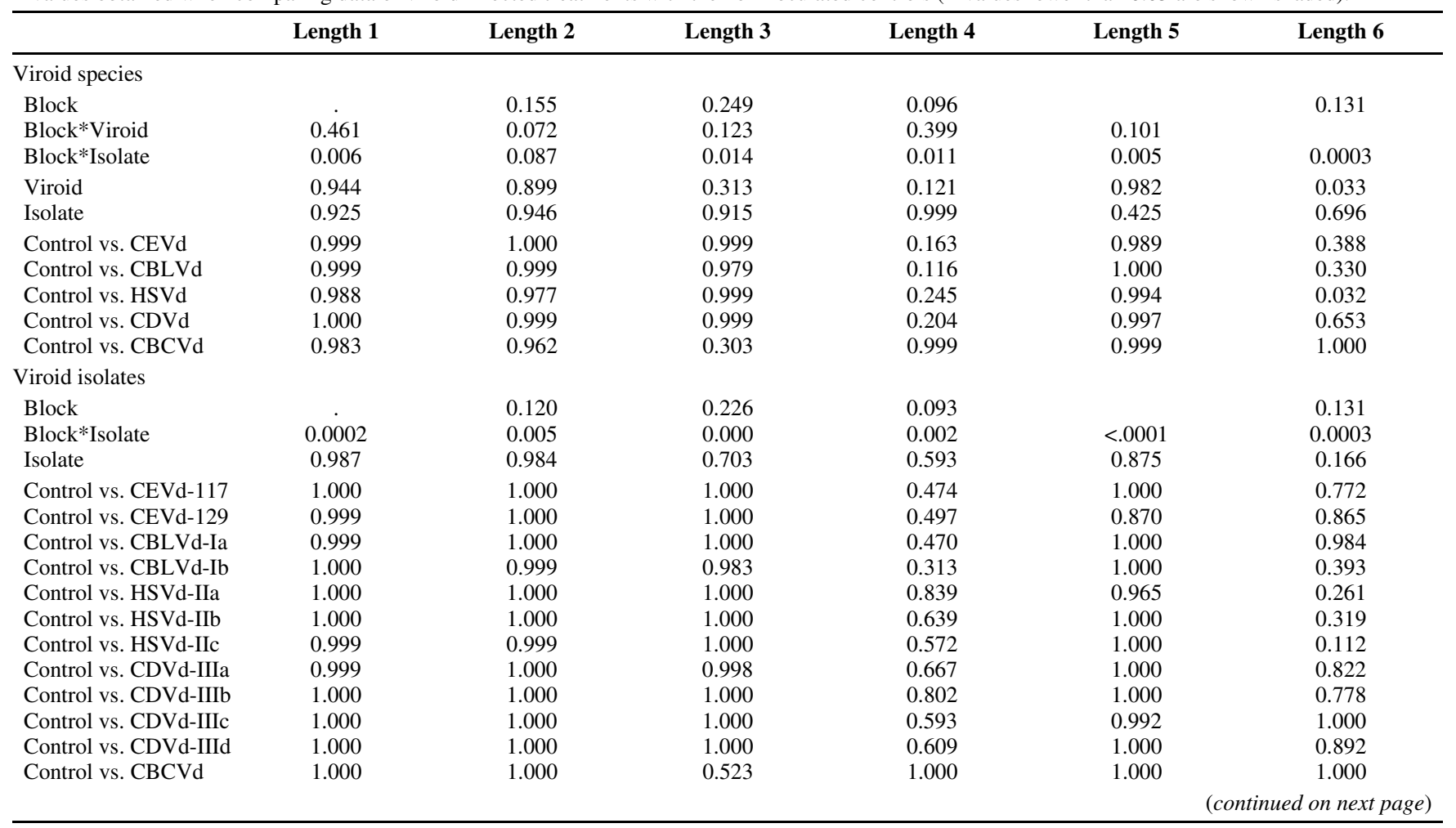

${ }^{\text {a }}$ Fruit height was measured in a random sample of 10 fruits per tree. Data were collected monthly from October until harvesting time. 
Field observations indicated that trees grafted on Troyer and Carrizo citranges were also viroid sensitive and developed mild exocortis symptoms, but only the effects of field sources containing several viroids had been reported $(3,32)$. The present study reports the results of an attempt to establish the effect of single viroid sources on the performance of Washington navel sweet orange trees grafted on Carrizo citrange.

Unexpectedly, no bark scaling symptoms characteristic of the exocortis disease were observed as a result of viroid infection. However, CEVd-infected trees presented small lesions in the roots, a mild form of the symptoms recently described in trees grafted on Carrizo citrange that were infected with a field isolate containing CEVd, HSVd, CBLVd, and CDVd (3). Several trees presented bark-cracking symptoms only consistently observed in trees infected with CBCVd or with the mild CEVd isolate (CEVd-129) as well as in the noninfected controls. In most instances, the bark cracking symptoms were mild and extended above the bud-union, suggesting that they might be the result of sunburn and not associated with viroid infection. However, in the case of CBCVdinfected trees, bark cracking was intense and mainly restricted to the rootstock, suggesting that it was a viroid induced effect as demonstrated earlier in trees grafted on trifoliate orange (48). As also reported earlier, the presence of pegs and gummy pits was not associated with viroid infection (48).

Infection with CEVd or CDVd also caused a slight reduction of tree growth and yield that was not as significant as reported in the case of trees grafted on trifoliate orange $(48,51)$. Unexpectedly, whereas CBCVd did not affect the growth of trees grafted on trifoliate orange $(48,51)$, the results of the present study showed that $\mathrm{CBCVd}$ infection caused the most significant reduction of tree

Table 6. (continued from previous page $)^{\mathrm{b}}$

\begin{tabular}{|c|c|c|c|c|c|c|c|c|c|c|c|c|}
\hline \multirow[b]{2}{*}{ Treatment } & \multicolumn{2}{|c|}{ Diameter $1(\mathbf{m m})$} & \multicolumn{2}{|c|}{ Diameter $2(\mathrm{~mm})$} & \multicolumn{2}{|c|}{ Diameter $3(\mathrm{~mm})$} & \multicolumn{2}{|c|}{ Diameter $4(\mathrm{~mm})$} & \multicolumn{2}{|c|}{ Diameter $5(\mathrm{~mm})$} & \multicolumn{2}{|c|}{ Diameter $6(\mathrm{~mm})$} \\
\hline & Mean & SE & Mean & SE & Mean & SE & Mean & SE & Mean & SE & Mean & SE \\
\hline \multicolumn{13}{|l|}{ Viroid species } \\
\hline Control & 72.49 & 0.731 & 75.96 & 0.808 & 78.24 & 0.952 & 77.99 & 0.978 & 78.35 & 0.999 & 83.85 & 1.493 \\
\hline CEVd & 71.27 & 0.521 & 75.30 & 0.656 & 77.81 & 0.782 & 77.03 & 0.781 & 78.53 & 0.835 & 81.88 & 1.100 \\
\hline CBLVd & 71.18 & 0.429 & 75.91 & 0.656 & 77.37 & 0.782 & 77.34 & 0.780 & 78.34 & 0.835 & 80.12 & 1.100 \\
\hline HSVd & 71.44 & 0.521 & 75.32 & 0.597 & 77.33 & 0.716 & 77.25 & 0.703 & 78.29 & 0.773 & 80.10 & 0.933 \\
\hline CDVd & 71.91 & 0.384 & 76.23 & 0.571 & 77.72 & 0.688 & 77.69 & 0.668 & 78.33 & 0.746 & 81.48 & 0.853 \\
\hline CBCVd & 71.56 & 0.731 & 76.31 & 0.808 & 79.54 & 0.952 & 79.34 & 0.978 & 78.99 & 0.999 & 83.71 & 1.492 \\
\hline \multicolumn{13}{|l|}{ Viroid isolates } \\
\hline Control & 72.49 & 0.731 & 75.96 & 0.813 & 78.25 & 0.946 & 78.25 & 0.946 & 78.25 & 0.946 & 83.85 & 1.493 \\
\hline CEVd-117 & 71.12 & 0.731 & 75.32 & 0.813 & 77.29 & 0.946 & 77.29 & 0.946 & 77.29 & 0.946 & 81.80 & 1.493 \\
\hline CEVd-129 & 71.43 & 0.731 & 75.28 & 0.813 & 78.33 & 0.946 & 78.33 & 0.946 & 78.33 & 0.946 & 81.99 & 1.493 \\
\hline CBLVd-Ia & 71.53 & 0.731 & 76.21 & 0.813 & 77.83 & 0.946 & 77.83 & 0.946 & 77.83 & 0.946 & 80.57 & 1.493 \\
\hline CBLVd-Ib & 71.35 & 0.731 & 75.61 & 0.813 & 76.92 & 0.946 & 76.92 & 0.946 & 76.92 & 0.946 & 79.66 & 1.493 \\
\hline HSVd-IIa & 71.45 & 0.731 & 75.53 & 0.813 & 77.30 & 0.946 & 77.30 & 0.946 & 77.30 & 0.946 & 79.47 & 1.493 \\
\hline HSVd-IIb & 70.91 & 0.731 & 74.93 & 0.813 & 76.92 & 0.946 & 76.92 & 0.946 & 76.92 & 0.946 & 81.07 & 1.493 \\
\hline HSVd-IIc & 71.18 & 0.731 & 75.50 & 0.813 & 77.78 & 0.946 & 77.78 & 0.946 & 77.78 & 0.946 & 79.76 & 1.493 \\
\hline CDVd -IIIa & 72.07 & 0.731 & 76.37 & 0.813 & 77.46 & 0.946 & 77.46 & 0.946 & 77.46 & 0.946 & 80.72 & 1.493 \\
\hline CDVd -IIIb & 71.10 & 0.731 & 75.84 & 0.813 & 76.92 & 0.946 & 76.92 & 0.946 & 76.92 & 0.946 & 81.42 & 1.493 \\
\hline CDVd -IIIc & 72.54 & 0.805 & 76.35 & 0.883 & 78.94 & 1.025 & 78.94 & 1.025 & 78.94 & 1.025 & 82.65 & 1.633 \\
\hline CDVd-IIId & 71.95 & 0.731 & 76.38 & 0.813 & 77.56 & 0.946 & 77.56 & 0.946 & 77.56 & 0.946 & 81.11 & 1.493 \\
\hline CBCVd & 71.56 & 0.731 & 76.31 & 0.813 & 79.54 & 0.946 & 79.54 & 0.946 & 79.54 & 0.946 & 83.71 & 1.493 \\
\hline
\end{tabular}

$P$ values obtained when comparing data of viroid infected treatments with the noninoculated controls.

\begin{tabular}{|c|c|c|c|c|c|c|}
\hline & Diameter 1 (mm) & Diameter 2 (mm) & Diameter 3 (mm) & Diameter 4 (mm) & Diameter 5 (mm) & Diameter $6(\mathrm{~mm})$ \\
\hline \multicolumn{7}{|l|}{ Viroid species } \\
\hline Block & 0.398 & 0.170 & 0.139 & 0.107 & 0.264 & 0.198 \\
\hline Block*Viroid & & 0.105 & 0.140 & 0.400 & 0.042 & \\
\hline Block* Isolate & 0.0003 & 0.074 & 0.019 & 0.029 & 0.042 & 0.0002 \\
\hline Viroid & 0.596 & 0.716 & 0.393 & 0.344 & 0.994 & 0.095 \\
\hline Isolate & 0.936 & 0.985 & 0.609 & 0.973 & 0.206 & 0.967 \\
\hline Control vs. CEVd & 0.446 & 0.908 & 0.990 & 0.757 & 1.000 & 0.609 \\
\hline Control vs. CBLVd & 0.569 & 1.000 & 0.851 & 0.927 & 1.000 & 0.115 \\
\hline Control vs. HSVd & 0.333 & 0.904 & 0.807 & 0.869 & 1.000 & 0.086 \\
\hline Control vs. CDVd & 0.890 & 0.997 & 0.971 & 0.996 & 1.000 & 0.376 \\
\hline Control vs. CBCVd & 0.769 & 0.996 & 0.672 & 0.615 & 0.981 & 1.000 \\
\hline \multicolumn{7}{|l|}{ Viroid isolates } \\
\hline Block & 0.397 & 0.130 & 0.119 & 0.102 & 0.148 & 0.198 \\
\hline Block*Viroid & 0.0003 & 0.007 & 0.001 & 0.007 & 0.001 & 0.0002 \\
\hline Block* Isolate & 0.912 & 0.948 & 0.579 & 0.797 & 0.807 & 0.481 \\
\hline Control vs. CEVd-117 & 0.777 & 0.999 & 0.990 & 0.999 & 1.000 & 0.944 \\
\hline Control vs. CEVd-129 & 0.937 & 0.998 & 1.000 & 0.939 & 0.984 & 0.968 \\
\hline Control vs. CBLVd-Ia & 0.968 & 1.000 & 1.000 & 1.000 & 1.000 & 0.556 \\
\hline Control vs. CBLVd-Ib & 0.904 & 1.000 & 0.909 & 0.986 & 1.000 & 0.276 \\
\hline Control vs. HSVd-IIa & 0.946 & 1.000 & 0.990 & 1.000 & 0.988 & 0.230 \\
\hline Control vs. HSVd-IIb & 0.626 & 0.954 & 0.910 & 0.956 & 0.905 & 0.745 \\
\hline Control vs. HSVd-IIc & 0.815 & 1.000 & 1.000 & 1.000 & 1.000 & 0.299 \\
\hline Control vs. CDVd-IIIa & 1.000 & 1.000 & 0.998 & 1.000 & 1.000 & 0.615 \\
\hline Control vs. CDVd-IIIb & 0.760 & 1.000 & 0.910 & 0.999 & 1.000 & 0.858 \\
\hline Control vs. CDVd-IIIc & 1.000 & 1.000 & 1.000 & 1.000 & 1.000 & 1.000 \\
\hline Control vs. CDVd-IIId & 1.000 & 1.000 & 1.000 & 1.000 & 1.000 & 0.757 \\
\hline Control vs. CBCVd & 0.975 & 1.000 & 0.917 & 0.897 & 1.000 & 1.000 \\
\hline
\end{tabular}

${ }^{\mathrm{b}}$ Fruit diameter was measured in a random sample of 10 fruits per tree. Data were collected monthly from October until harvesting time. 
Table 7. External quality parameters of fruits from viroid (species and isolates) infected Washington navel sweet orange trees grafted on citrange Carrizo

\begin{tabular}{|c|c|c|c|c|c|c|c|c|c|c|}
\hline \multirow[b]{2}{*}{ Treatment } & \multicolumn{2}{|c|}{ Diameter/lengtha } & \multicolumn{2}{|c|}{ Rind thickness (mm) } & \multicolumn{2}{|c|}{ Fruit weight $(g)^{b}$} & \multicolumn{2}{|c|}{ Fruit size $(\mathrm{ml})^{b}$} & \multicolumn{2}{|c|}{ Fruit density $(\mathrm{g} / \mathrm{ml})$} \\
\hline & Mean & SE & Mean & SE & Mean & SE & Mean & SE & Mean & SE \\
\hline \multicolumn{11}{|l|}{ Viroid species } \\
\hline Control & 1.01 & 0.009 & 5.10 & 0.120 & 2933.3 & 131.14 & 3278.7 & 147.88 & 0.90 & 0.006 \\
\hline CEVd & 1.01 & 0.007 & 5.08 & 0.091 & 2747.5 & 98.21 & 3098.7 & 111.73 & 0.89 & 0.005 \\
\hline CBLVd & 1.03 & 0.007 & 5.16 & 0.091 & 2667.5 & 98.21 & 3008.5 & 111.73 & 0.89 & 0.006 \\
\hline HSVd & 1.01 & 0.005 & 4.99 & 0.079 & 2623.3 & 84.43 & 2910.7 & 96.72 & 0.90 & 0.004 \\
\hline CDVd & 1.02 & 0.005 & 4.93 & 0.074 & 2825.6 & 77.93 & 3129.4 & 89.68 & 0.90 & 0.004 \\
\hline CBCVd & 1.01 & 0.009 & 5.09 & 0.120 & 3041.3 & 131.14 & 3378.5 & 147.88 & 0.90 & 0.006 \\
\hline \multicolumn{11}{|c|}{ Viroid isolates } \\
\hline Control & 1.01 & 0.009 & 5.10 & 0.120 & 2933.3 & 131.14 & 3278.7 & 147.88 & 0.90 & 0.006 \\
\hline CEVd-117 & 1.01 & 0.009 & 5.02 & 0.120 & 2742.0 & 131.14 & 3116.7 & 147.88 & 0.88 & 0.006 \\
\hline CEVd-129 & 1.01 & 0.009 & 5.13 & 0.120 & 2753.0 & 131.14 & 3080.7 & 147.88 & 0.90 & 0.006 \\
\hline CBLVd-Ia & 1.03 & 0.009 & 5.13 & 0.120 & 2753.7 & 131.14 & 3107.7 & 147.88 & 0.89 & 0.006 \\
\hline CBLVd-Ib & 1.02 & 0.009 & 5.19 & 0.120 & 2581.3 & 131.14 & 2909.3 & 147.88 & 0.89 & 0.006 \\
\hline HSVd-IIa & 1.02 & 0.009 & 4.84 & 0.120 & 2657.0 & 131.14 & 2931.0 & 147.88 & 0.91 & 0.006 \\
\hline HSVd-IIb & 1.00 & 0.009 & 5.35 & 0.120 & 2645.0 & 131.14 & 2981.3 & 147.88 & 0.89 & 0.006 \\
\hline HSVd-IIc & 1.01 & 0.009 & 4.79 & 0.120 & 2568.0 & 131.14 & 2819.7 & 147.88 & 0.91 & 0.006 \\
\hline CDVd-IIIa & 1.02 & 0.009 & 4.87 & 0.120 & 2789.2 & 131.14 & 3089.0 & 147.88 & 0.90 & 0.006 \\
\hline CDVd-IIIb & 1.01 & 0.009 & 4.96 & 0.120 & 2790.3 & 131.14 & 3097.2 & 147.88 & 0.90 & 0.006 \\
\hline CDVd-IIIc & 1.03 & 0.010 & 4.99 & 0.132 & 2990.8 & 143.02 & 3310.6 & 161.00 & 0.90 & 0.007 \\
\hline CDVd-IIId & 1.02 & 0.009 & 4.89 & 0.120 & 2732.0 & 131.14 & 3020.7 & 147.88 & 0.91 & 0.006 \\
\hline CBCVd & 1.01 & 0.009 & 5.09 & 0.120 & 3041.3 & 131.14 & 3378.5 & 147.88 & 0.90 & 0.006 \\
\hline
\end{tabular}

$P$ values obtained when comparing data of viroid infected treatments with the noninoculated controls $(P$ values lower than 0.05 are shown shaded).

\begin{tabular}{|c|c|c|c|c|c|}
\hline & Diameter/length & Rind thickness (mm) & Fruit weight (g) & Fruit size (ml) & Fruit density (g/ml) \\
\hline \multicolumn{6}{|l|}{ Viroid species } \\
\hline Block & & 0.460 & 0.159 & 0.145 & 0.250 \\
\hline Block*Viroid & & 0.160 & & & \\
\hline Block*Isolate & 0.003 & 0.115 & - & - & - \\
\hline Viroid & 0.154 & 0.432 & 0.033 & 0.041 & 0.014 \\
\hline Isolate & 0.811 & 0.032 & 0.829 & 0.775 & 0.189 \\
\hline Control vs. CEVd & 1.000 & 1.000 & 0.530 & 0.643 & 0.785 \\
\hline Control vs. CBLVd & 0.188 & 0.985 & 0.234 & 0.306 & 0.554 \\
\hline Control vs. HSVd & 0.926 & 0.897 & 0.104 & 0.077 & 0.694 \\
\hline Control vs. CDVd & 0.377 & 0.574 & 0.845 & 0.719 & 0.623 \\
\hline Control vs. CBCVd & 1.000 & 1.000 & 0.927 & 0.964 & 0.990 \\
\hline \multicolumn{6}{|l|}{ Viroid isolates } \\
\hline Block & & 0.420 & 0.159 & 0.145 & 0.250 \\
\hline Block*Isolate & 0.003 & 0.020 & & & \\
\hline Isolate & 0.467 & 0.072 & 0.206 & 0.210 & 0.024 \\
\hline Control vs. CEVd-117 & 1.000 & 1.000 & 0.909 & 0.984 & 0.643 \\
\hline Control vs. CEVd-129 & 1.000 & 1.000 & 0.935 & 0.940 & 1.000 \\
\hline Control vs. CBLVd-Ia & 0.379 & 1.000 & 0.937 & 0.978 & 0.893 \\
\hline Control vs. CBLVd-Ib & 0.743 & 1.000 & 0.300 & 0.368 & 0.964 \\
\hline Control vs. HSVd-IIa & 0.805 & 0.649 & 0.585 & 0.440 & 0.780 \\
\hline Control vs. HSVd-IIb & 1.000 & 0.636 & 0.535 & 0.627 & 0.993 \\
\hline Control vs. HSVd-IIc & 1.000 & 0.421 & 0.261 & 0.155 & 0.377 \\
\hline Control vs. CDVd-IIIa & 0.893 & 0.767 & 0.986 & 0.955 & 0.964 \\
\hline Control vs. CDVd-IIIb & 0.999 & 0.989 & 0.986 & 0.966 & 1.000 \\
\hline Control vs. CDVd-IIIc & 0.511 & 0.999 & 1.000 & 1.000 & 0.988 \\
\hline Control vs. CDVd-IIId & 0.867 & 0.839 & 0.881 & 0.775 & 0.893 \\
\hline Control vs. CBCVd & 1.000 & 1.000 & 0.999 & 1.000 & 1.000 \\
\hline
\end{tabular}

a Diameter, length, and rind thickness are the average measurements of the 10 fruits sampled from each tree.

${ }^{b}$ Fruit weight and size were measured as the overall weight and volume of samples of 10 fruits collected from each tree.

size (height and canopy volume). As reported by Bani Hashemian et al. (3), reduction of tree size was associated with a small root system.

CBCVd-infected trees, in spite of producing smaller yields than the noninfected controls, resulted in a good yield efficiency (yield/canopy volume). The $P$ values, however, were not small enough to infer if the differences were statistically significant. Further assays with larger numbers of trees would be necessary to confirm the sensitivity of Carrizo citrange to CBCVd infection and to postulate its usefulness to control tree size in high-density plantations. With the exception of fruits harvested from HSVd-infected trees that presented a smaller caliber, viroid infection did not affect any of the fruit quality parameters evaluated.

In summary, the results of this study indicate that under the growing conditions in which the assay was performed, viroid infection reduced height and canopy volume and affected fruit size without reducing yield. CBCVd produced interesting effects because in spite of reducing tree size, productivity and fruit size were enhanced. However, these results must be taken with caution because field isolates usually contain several viroids and the effect of mixed infections has been shown to affect the performance of the trees, as has been recently shown in a field assay conducted with 'Nules' clementine and 'Navelina' sweet orange trees grafted on Carrizo citrange (3), as well as in low performing commercial orchards of 'Nules' clementine and 'Ortanique' tangor ( $C$. reticulata $\times C$. sinensis), also grafted on Carrizo citrange (2). If the sensitivity of Carrizo citrange to CBCVd is confirmed, this viroid would be the best candidate to control the size of trees grafted on Carrizo citrange in high density plantings, as suggested in the case of CDVd for trees grafted on trifoliate orange (50). 
Table 8. Internal quality parameters of fruits from viroid (species and isolates) infected Washington navel sweet orange trees grafted on citrange Carrizo

\begin{tabular}{|c|c|c|c|c|c|c|c|c|c|c|}
\hline \multirow[b]{2}{*}{ Treatment } & \multicolumn{2}{|c|}{ Juice volume (ml) ${ }^{\mathbf{a}}$} & \multicolumn{2}{|c|}{ Juice density (g/ml) } & \multicolumn{2}{|c|}{ Soluble solids (\%) } & \multicolumn{2}{|c|}{ Total acidity (\%) } & \multicolumn{2}{|c|}{ Maturity index } \\
\hline & Mean & SE & Mean & SE & Mean & SE & Mean & SE & Mean & SE \\
\hline \multicolumn{11}{|l|}{ Viroid species } \\
\hline Control & 1156.7 & 53.10 & 1.05 & 0.004 & 14.00 & 0.215 & 1.48 & 0.109 & 9.64 & 0.749 \\
\hline CEVd & 1079.7 & 41.27 & 1.05 & 0.003 & 13.50 & 0.160 & 1.30 & 0.082 & 10.77 & 0.561 \\
\hline CBLVd & 1079.7 & 41.27 & 1.06 & 0.003 & 13.89 & 0.160 & 1.37 & 0.082 & 10.39 & 0.561 \\
\hline HSVd & 1041.1 & 36.49 & 1.05 & 0.003 & 13.89 & 0.136 & 1.42 & 0.071 & 9.94 & 0.483 \\
\hline CDVd & 1109.3 & 34.34 & 1.05 & 0.003 & 13.55 & 0.125 & 1.30 & 0.065 & 10.90 & 0.446 \\
\hline CBCVd & 1185.8 & 53.10 & 1.05 & 0.004 & 13.60 & 0.215 & 1.29 & 0.109 & 10.83 & 0.749 \\
\hline \multicolumn{11}{|l|}{ Viroid isolates } \\
\hline Control & 1156.7 & 53.32 & 1.05 & 0.003 & 14.00 & 0.215 & 1.483 & 0.109 & 9.64 & 0.749 \\
\hline CEVd-117 & 1088.3 & 53.32 & 1.05 & 0.003 & 13.50 & 0.215 & 1.387 & 0.109 & 10.42 & 0.749 \\
\hline CEVd-129 & 1070.0 & 53.32 & 1.05 & 0.003 & 13.50 & 0.215 & 1.222 & 0.109 & 11.12 & 0.749 \\
\hline CBLVd-Ia & 1123.3 & 53.32 & 1.06 & 0.003 & 13.92 & 0.215 & 1.350 & 0.109 & 10.35 & 0.749 \\
\hline CBLVd-Ib & 1035.0 & 53.32 & 1.06 & 0.003 & 13.87 & 0.215 & 1.383 & 0.109 & 10.42 & 0.749 \\
\hline HSVd-IIa & 981.7 & 53.32 & 1.06 & 0.003 & 13.85 & 0.215 & 1.465 & 0.109 & 9.58 & 0.749 \\
\hline HSVd-IIb & 1090.0 & 53.32 & 1.05 & 0.003 & 13.73 & 0.215 & 1.382 & 0.109 & 10.03 & 0.749 \\
\hline HSVd-IIc & 1051.7 & 53.32 & 1.06 & 0.003 & 14.10 & 0.215 & 1.418 & 0.109 & 10.20 & 0.749 \\
\hline CDVd -IIIa & 1103.3 & 53.32 & 1.05 & 0.003 & 13.57 & 0.215 & 1.233 & 0.109 & 11.42 & 0.749 \\
\hline CDVd -IIIb & 1080.0 & 53.32 & 1.05 & 0.003 & 13.45 & 0.215 & 1.280 & 0.109 & 11.04 & 0.749 \\
\hline CDVd -IIIc & 1194.9 & 58.06 & 1.05 & 0.003 & 13.23 & 0.235 & 1.235 & 0.119 & 10.94 & 0.817 \\
\hline CDVd -IIId & 1058.3 & 53.32 & 1.05 & 0.003 & 13.97 & 0.215 & 1.445 & 0.109 & 10.20 & 0.749 \\
\hline CBCVd & 1185.8 & 53.32 & 1.05 & 0.003 & 13.60 & 0.215 & 1.285 & 0.109 & 10.83 & 0.749 \\
\hline & \multicolumn{2}{|c|}{ Juice volume } & \multicolumn{2}{|c|}{ Juice density } & \multicolumn{2}{|c|}{ Soluble solids } & \multicolumn{2}{|c|}{ Total acidity } & \multicolumn{2}{|c|}{ Maturity index } \\
\hline \multicolumn{11}{|l|}{ Viroid species } \\
\hline Block & \multicolumn{2}{|c|}{0.191} & \multicolumn{2}{|c|}{0.410} & \multicolumn{2}{|c|}{0.181} & \multicolumn{2}{|c|}{0.1542} & & \\
\hline Block*Viroid & & & & & & & & & & \\
\hline Viroid & & & & & & & & & & \\
\hline Isolate & & & & & & & & & & \\
\hline Control vs. CEVd & & & & & & & & & & \\
\hline Control vs. CBLVd & & & & & & & & & & \\
\hline Control vs. HSVd & & & & & & & & & & \\
\hline Control vs. CDVd & & & & & & & & & & \\
\hline Control vs. CBCVd & & & & & & & & & & \\
\hline Viroid isolates & & & & & & & & & & \\
\hline Block & & & & & & & & & & \\
\hline Isolate & & & & & & & & & & \\
\hline Control vs. CEVd-117 & & & & & & & & & & \\
\hline Control vs. CEVd-129 & & & & & & & & & & \\
\hline Control vs. CBLVd-Ia & & & & & & & & & & \\
\hline Control vs. CBLVd-Ib & & & & & & & & & & \\
\hline Control vs. HSVd-IIa & & & & & & & & & & \\
\hline Control vs. HSVd-IIb & & & & & & & & & & \\
\hline Control vs. HSVd-IIc & & & & & & & & & & \\
\hline Control vs. CDVd-IIIa & & & & & & & & & & \\
\hline Control vs. CDVd-IIIb & & & & & & & & & & \\
\hline Control vs. CDVd-IIIc & & & & & & & & & & \\
\hline Control vs. CDVd-IIId & & & & & & & & & & \\
\hline Control vs. CBCVd & & & & & & & & & & \\
\hline
\end{tabular}

a Juice extracted from samples of 10 randomly collected fruits.

\section{Acknowledgments}

This research was supported by grants AGL2008-01491 and AGL2012-32429 from the Ministerio de Ciencia y Tecnología (Spain). S. M. Bani Hashemian and N. Murcia are recipients of fellowships from the Iran Citrus Research Institute and CORPOICA (NM), respectively. The authors thank Rosario Carbó for technical assistance and J. M. Bové and S. Riza for their help in collecting field data.

\section{Literature Cited}

1. Ashulin, L., Lachman, O., Hadas, R., and Bar-Joseph M. 1991. Nucleotide sequence of a new viroid species, citrus bent leaf viroid (CBLVd) isolated from grapefruit in Israel. Nucleic Acids Res. 19:4767.

2. Bani Hashemian, S. M., Murcia, N., Trenor, I., and Duran-Vila, N. 2010. Low performance of citrus trees grafted on Carrizo citrange is associated with viroid infection. J. Plant Pathol. 92:511-517.

3. Bani Hashemian, S. M., Serra, P., Barbosa, C. J., Juárez, J., Aleza, P., Corvera, J. M., Lluch, A., Pina, J. A., and Duran-Vila, N. 2009. The effect of a field-source mixture of citrus viroids on the performance of 'Nules' clementine and 'Navelina' sweet orange trees grafted on Carrizo citrange. Plant Dis. 93:699-707.

4. Ben-Shaul, A., Guang, Y., Mogilner, N., Hadas, R., Mawassi, M., Gafney,
R., and Bar-Joseph, M. 1995. Genomic diversity among populations of two citrus viroids from different graft-transmissible dwarfing complexes in Israel. Phytopathology 85:359-364.

5. Benton, R. J., Bowman, F. T., Fraser, L., and Kebby, R. G. 1949. Selection of citrus budwood to control scaly butt in trifoliata rootstock. Agric. Gaz. N.S.W. 60:31-34.

6. Benton, R. J., Bowman, F. T., Fraser, L., and Kebby, R. G. 1950. Stunting and scaly butt associated with Poncirus trifoliata rootstock. N.S.W. Dep. Agric. Sci. Bull. 70:1-20.

7. Bernad, L., Duran-Vila, N., and Elena, S. F. 2009. Effect of citrus hosts on the generation, maintenance and evolutionary fate of genetic variability of citrus exocortis viroid. J. Gen. Virol. 90:2040-2049.

8. Chaffai, M., Serrra, P., Gandía, M., Hernández, C., and Duran-Vila, N. 2007. Molecular characterization of CEVd strains that induce different phenotyes in Gynura aurantiaca: Structure-pathogenicity relationships. Arch. Virol. 152:1283-1294.

9. Childs, J. F. L. 1950. The cachexia disease of Orlando tangelo. Plant Dis. Rep. 34:295-298.

10. Diener, T. O. 1971. Potato spindle tuber "virus" IV. A replicating, low molecular weight RNA. Virology 45:411-428.

11. Duran-Vila, N., Flores, R., and Semancik, J. S. 1986. Characterization of 
viroid-like RNAs associated with the citrus exocortis syndrome. Virology 150:75-84.

12. Duran-Vila, N., Roistacher, C. N., Rivera-Bustamante, R., and Semancik, J. S. 1988. A definition of citrus viroid groups and their relationship to the exocortis disease. J. Gen. Virol. 69:3069-3080.

13. Fawcett, H. S., and Klotz, L. J. 1948. Exocortis on trifoliate orange. Citrus Leaves 28:8.

14. Fernández-Valiela, M. V., Fortugno, C., and Corizzi, F. 1965. Incidence of bud-union crease in citrus trees grafted on trifoliata rootstock in the Delta del Paraná and San Pedro areas of Argentina. Pages 182-186 in: Proc. 3rd Conf. IOCV. IOCV, Riverside, CA.

15. Foguet, J. L., and Oste, C. A. 1968. Disorders of trifoliate orange rootstock in Tucumán, Argentina. Pages 183-189 in: Proc. 4th Conf. IOCV. IOCV, Riverside, CA.

16. Foissac, X., and Duran-Vila, N. 2000. Characterization of two citrus apscaviroids isolated in Spain. Arch. Virol. 145:1975-1983.

17. Francis, M., Szychowski, J. A., and Semancik, J. S. 1995. Structural sites specific to citrus viroid groups. J. Gen. Virol. 76:1081-1089.

18. Fraser, L. R., and Levitt, E. C. 1959. Recent advances in the study of exocortis (scaly butt) in Australia. Pages 129-133 in: Citrus Diseases. University of California. Div. Agric. Sci.

19. Gandía, M., and Duran-Vila, N. 2004. Variability of the progeny of a sequence variant of Citrus Bent Leaf Viroid (CBLVd). Arch. Virol. 149:407416.

20. Gandía, M., Rubio, L., Palacio, A., and Duran-Vila, N. 2005. Genetic variation and population structure of a Citrus exocortis viroid (CEVd) isolate and the progenies of infectious haplotypes. Arch. Virol. 150:19451957.

21. Gillings, M. R., Broadbent, P., and Gollow, B. I. 1991. Viroids in Australian Citrus: Relationship to exocortis, cachexia and citrus dwarfing. Aust. J. Plant Physiol. 18:559-570.

22. Hutton, R. J., Broadbent, P., and Bevington, K. B. 2000. Viroid dwarfing from high density citrus plantings. Hortic. Rev. 24:277-317.

23. Ito, T., Ieki, H., Ozaki, K., and Ito, T. 2001. Characterization of a new citrus viroid species tentatively termed Citrus viroid OS. Arch. Virol. 146:975982.

24. Jiménez-Cuesta, M., Cuquerella, J., and Martínez-Jávega, J. M. 1981. Determination of a color index for citrus fruit degreening. Proc. 4th Int. Citrus Congr. International Society of Citriculture, Tokyo, Japan. 2:750752.

25. Marais, J., Lee, R. F., Breytenbach, J. H. J., Manicom, B. Q., and Vanvuuren, S. P. 1996. Association of a viroid with Gum Pocket disease of trifoliate orange. Pages 236-244 in: Proc. 13th Conf. IOCV. IOCV, Riverside, CA.

26. Murcia, N., Bernad, L., Duran-Vila, N., and Serra, P. 2011. Two nucleotide positions in the Citrus exocortis viroid RNA associated with symptom expression in Etrog citron but not in experimental herbaceous hosts. Mol. Plant Pathol. 12:203-208.

27. Murcia, N., Bernad, L., Serra, P., Bani Hashemian, S. M., and Duran-Vila, N. 2009. Molecular and biological characterization of natural variants of Citrus dwarfing viroid. Arch. Virol. 152:1283-1294.

28. Murcia, N., Serra, P., Olmos, A., and Duran-Vila, N. 2008. A novel hybridization approach for detection of citrus viroids. Mol. Cell. Probes 23:95-102.

29. Nour-Eldin, F. 1956. Phloem discoloration of sweet orange. Phytopathology 46:238-239.

30. Palacio, A., Foissac, X., and Duran-Vila, N. 2000. Indexing of citrus viroids by imprint hybridisation. Eur. J. Plant Pathol. 105:897-903.

31. Palacio-Bielsa, A., Romero-Durbán, J., and Duran-Vila, N. 2004. Characterization of citrus HSVd isolates. Arch. Virol. 149:537-552.

32. Polizzi, G., Albanese, G., Azzaro, A., Davino, M., and Catara, A. 1991. Field evaluation of dwarfing effect of two combinations of citrus viroids on different citrus species. Pages 230-233 in: Proc. Conf. Int. Organ. Citrus Virol. 11th. IOCV, Riverside, CA.
33. Puchta, H., Ramm, K., Luckinger, R., Hadas, R., Bar-Joseph, M., and Sänger, H. L. 1991. Primary and secondary structure of citrus viroid IV (CVd IV), a new chimeric viroid present in dwarfed grapefruit in Israel. Nucleic Acids Res. 19:6640.

34. Rakowski, A. G., Szychowski, J. A., Avena, Z. S., and Semancik, J. S. 1994 Nucleotide sequence and structural features of the Group III citrus viroids J. Gen. Virol. 75:3581-3584.

35. Reanwarakorn, K., and Semancik, J. S. 1998. Regulation of pathogenicity in hop stunt viroid related group II citrus viroids. J. Gen. Virol. 79:31633171 .

36. Roistacher, C. N. 1983. Cachexia disease: Virus or viroid. Citrograph 28:11113.

37. Roistacher, C. N., Calavan, E. C., Blue, R. L., Navarro, L., and Gonzales, R. 1977. A new more sensitive citron indicator for the detection of mild isolates of citrus exocortis viroid (CEV). Plant Dis. Rep. 61:135-139.

38. Sano, T., Hataya, T., and Shikata, E. 1988. Complete nucleotide sequence of a viroid aisolate from Etrog citron, a new member of hop stunt viroid group. Nucleic Acids Res. 16:347.

39. Schlemmer, A., Roistacher, C. N., and Semancik, J. S. 1985. A unique, infectious RNA associated with citron showing symptoms typical of citrus exocortis disease. Phytopathology 75:946-949.

40. Schwarz, R. E., and McClean, A. P. D. 1969. Gum-pocket, a new virus-like disease of Poncirus trifoliata. Plant Dis. Rep. 53:336-339.

41. Semancik, J. S., Morris, T. J., Weathers, L. G., Rodorf, G. F., and Kearns, D R. 1975. Physical properties of a minimal infectious RNA (viroid) associated with the exocortis disease. Virology 63:160-167.

42. Semancik, J. S., Rakowski, A. G., Bash, J. A., and Gumpf, D. J. 1997. Application of selected viroids for dwarfing and enhancement of production of "Valencia" orange. J. Hortic. Sci. 72:563-570.

43. Semancik, J. S., Roistacher, C. N., Rivera-Bustamante, R., and Duran-Vila, N 1988. Citrus cachexia viroid, a new viroid of citrus: Relationship to viroids of the exocortis disease complex. J. Gen. Virol. 69:3059-3068

44. Semancik, J. S., and Weathers, L. G. 1972. Exocortis disease: Evidence for a new species of "infectious" low molecular weight RNA in plants. Nature New Biol. 237:242-244.

45. Serra, P., Barbosa, C. J., Daròs, J. A., Flores, R., and Duran-Vila, N. 2008 Citrus viroid V: Molecular characterization and synergistic interactions with other members of the genus Apscaviroid. Virology 370:102-112.

46. Serra, P., Eiras, M., Bani Hashemian, S. M., Murcia, N., Kitajima, E. W. Daròs, J. A., Flores, R., and Duran-Vila, N. 2008. Citrus viroid V: Occurrence, host range, diagnosis, and identification of new variants. Phytopathology 98:1199-1204.

47. Serra, P., Gago, S., and Duran-Vila, N. 2008. A single nucleotide change in hop stunt viroid modulates citrus cachexia symptoms. Virus Res. 138:130 134.

48. Vernière, C., Perrier, X., Dubois, C., Dubois, A., Botella, L., Chabrier, C. Bové, J. M., and Duran-Vila, N. 2004. Citrus viroids: Symptom expression and effect on vegetative growth and yield of clementine trees grafted on trifoliate orange. Plant Dis. 88:1189-1197.

49. Vernière, C., Perrier, X., Dubois, C., Dubois, A., Botella, L., Chabrier, C., Bové, J. M., and Duran Vila, N. 2006. Interactions between citrus viroids affect symptom expression and field performance of clementine trees grafted on trifoliate orange. Phytopathology 96:356-368.

50. Vidalakis, G., Pagliaccia, D., Bash, J. A., Afunian, M., and Semancik, J. S. 2011. Citrus dwarfing viroid: Effects on tree size and scion performance specific to Poncirus trifoliata rootstock for high-density planting. Ann Appl. Biol. 158:204-217.

51. Vidalakis, G., Pagliaccia, D., Bash, J. A., and Semancik, J. S. 2010. Effects of mixtures of citrus viroids as transmissible small nuclear RNA on tree dwarfing and commercial scion performance on Carrizo citrange rootstock. Ann. Appl. Biol. 157:415-423.

52. Visvader, J. E., and Symons, R. H. 1986. Replication of in-vitro constructed viroid mutants: Location of the pathogenicity-modulating domain of citrus exocortis viroid. EMBO J. 5:2051-2055. 